\title{
UNA HISTORIA EN UN MUNDO PRIMORDIAL UNA REFLEXIÓN SOBRE ARTE, CIUDADANÍA Y UNIVERSIDAD (1) \\ Artículo de reflexión
}

\section{Adrián Serna Dimas}

Universidad Distrital Francisco José de Caldas / erazande@yahoo.es

Antropólogo egresado de la Universidad Nacional de Colombia, dedicado al estudio de las relaciones entre la cultura y el poder en diferentes contextos. He realizado investigaciones etnográficas y antropológicas en distintas regiones del país: Sabana de Bogotá, Magdalena Medio, Carare, Sarare, Llanos Orientales, Alto Caquetá, Bajo Putumayo, occidente de Boyacá y Valle del Cauca. Desde hace quince años trabaja en la cuestión de la memoria y el conflicto. 
SERNA DIMAS A, (2013) Una historia en un mundo primordial. Una reflexión sobre arte ciudadanía y Universidad. Calle 14, 7 (10), 15-43.

\section{RESUMEN}

El siguiente relato propone modos de relacionar el arte, la ciudadanía y la universidad desde los horizontes de lo simbólico. Un primer momento del relato está orientado a establecer el estatus de la alegoría y del arte alegórico; un segundo momento reflexiona sobre el Estado desde la distinción clásica de lo sagrado y lo profano, haciendo énfasis en la relevancia del arte alegórico para representar la fuerza sagrada del Estado; un tercer momento devela la relación entre Estado y arte alegórico a propósito de la escuela como instancia de socialización, y, de modo más concreto, de la universidad como institución social; finalmente, el relato propone una discusión sobre las relaciones entre cultura y arte y los riesgos que supone para estas la colonización del mundo vital por parte de la mercancía. Aunque aquí se trata de una reflexión desde diferentes lugares teóricos, se privilegian algunos: la historia del arte y la cultura en Warburg y Panofsky, las estructuras del imaginario en Durand y la economía de los bienes simbólicos de Bourdieu.

\section{PALABRAS CLAVES}

Trashumancia de los símbolos, imagen superviviente, estructura del imaginario, poder simbólico, arte alegórico, ciudadanía, universidad

\section{A STORY IN A PRIMORDIAL WORLD: A REFLECTION ON ART, CITIZENSHIP AND ACADEMIA}

\section{ABSTRACT}

The following account proposes ways of connecting art, citizenship and the university from the horizons of the symbolic. A first moment in the story is aimed at establishing the status of allegory and allegorical art; a second moment reflects on the state from the classical distinction of the sacred and the profane, emphasizing the relevance of allegorical art to represent the sacred force of the state; a third reveals the relationship between the state and allegorical art while dealing with school as an instance of socialization, and, more specifically, of the university as a social institution; finally, the story proposes a discussion on the relationship between culture and art and the risks that the colonization of the world of life by the commodity poses to both. Although this reflection comes from different theoretical places, we privilege a few: the history of art and culture in Warburg and Panofsky, the structures of the imaginary in Durand and the economy of symbolic goods in Bourdieu.

\section{KEY WORDS}

Transhumance of symbols, surviving image, structure of the imaginary, symbolic power, allegorical art, citizenship, academia 


\section{UNE HISTOIRE DANS UN MONDE PRIMORDIAL, UNE RÉFLEXION SUR L'ART, LA CITOYENNETÉ ET L'UNIVERSITÉ}

\section{RÉSUMÉ}

Le présent document propose de modes de relations entre l'art, la citoyenneté et l'université à partir d'un horizon symbolique. Dans un premier temps, le récit est orienté à établir le statut de l'allégorique et de l'art allégorique; dans un second temps, une réflexion à propos de I 'État est développée, basée sur la distinction classique du sacré et du profane, en soulignant l'importance de l'art allégorique dans la représentation de la force sacrée de l'État; en troisième lieu est décelée la relation entre art allégorique et État, à propos de l'école comme instance de socialisation, et de façon plus concrète, de l'université en tant qu'institution sociale. Finalement, le document propose une discussion sur les relations entre culture et art et les risques que pour celles -ci suppose la colonisation du monde vital par la marchandise. Si bien cette réflexion est abordée depuis plusieurs points de vue théoriques, certains sont privilégiés comme l'histoire de l'art et la culture chez Warburg et Panofsky, le structures de l'imaginaire chez Durand et l'économie des biens symboliques chez Bourdieu.

\section{MOTS CLÉS}

Transhumance des symboles, image survivante, structure de l'imaginaire, pouvoir symbolique, art allégorique, citoyenneté, université

\section{UMA HISTÓRIA EM UM MUNDO PRIMORDIAL: UMA REFLEXÃO SOBRE ARTE, CIDADANIA E UNIVERSIDADE}

\section{RESUMO}

Este relato propõe modos de relacionar a arte, a cidadania e a universidade desde os horizontes do simbólico. A primeira parte do relato está orientada a estabelecer o estado da alegoria e da arte alegórica, um segundo momento reflexiona sobre o Estado desde a distinção clássica do sagrado e o profano, fazendo ênfases na relevância da arte alegórica para representar a força sagrada do Estado, um terceiro momento desvela a relação entre Estado e a arte alegórica, a propósito da escola como instância de socialização e, de modo mais concreto, da universidade como instituição social. Finalmente, o relato propõe uma discussão sobre as relações entre cultura e arte e os riscos que supõe para estas a colonização do mundo vital por parte da mercadoria. Apesar de que se trate de uma reflexão desde diferentes lugares teóricos, se privilegiam alguns: a história da arte e a cultura em Warburg e Panofsky, as estruturas do imaginário em Durand e a economia dos bens simbólicos de Bourdieu.

\section{PALAVRAS-CHAVE}

Transumância dos símbolos, imagem sobrevivente, estrutura do imaginário, poder simbólico, arte alegórico, cidadania, universidade 


\section{SUG ÑUGPAMANDA PARRLU KAI ATUN ALPAMANDA MINISTIDU: RRURRAIKUNAMANDA IUIAIKUNA, ATUN ALPAMANDA RRUNAKUNA Y ATUN UASI IACHAIKUDIRRU}

\section{UCHULLAIACHI}

Kai kilkaska kauachi imasa ainingapa rurraikunata, atun alpamanda runakunaua i atun uaisi iachaikudirruua karrumandata iuiarrispalla. Kai parrlu ñugpa kan ñambichiska kauachingapa imasam suiuchi iuiarriska i iuiarrispalla rrurraita; iskai ñambi katichiska iuiachirri atun alpamanda kaugsagkunata kauagkunamanda rrigsichirri imamka allilla imamka nan allilla, ikutipas ñugpachispa iuiarriskallata rrurraskata kauachingapa mana sambaiaspa allita apankuna atun alpamanda kaugsagkunata kauagkuna; kimsa katichiska tarri imasam maki kuarrinaku Atun alpamanda kaugsagkunata kauagkunaua y iuiarrispalla rrurradurrkunaua iachaikudirru tukuikunata tandchispa rrimanakungapa, allilla nispa, atun uaisi iachaikudirru sug atun uasi tukuikunamandasina; ña tukuchingapa, kilkaska churra rrimanakungapa kaugsaimanda iachaikuna i rrurraikuna i imasa man allilla ñambita rrirrigpi iuia atun alpapi kaska rrunakunamanda katudurrkunamanda. Paipi parrlitarri sugnigmanda sugnigmanda iuiaikuna, ñugpachi sugkunata: ñugpamanda rrurraikuna i kaugsaikunamanda iachaikunamanda Warburg y Panofskypa, imasanka allichiska Durandpa iuairriskapi i atun alpapi tukuikunamanda suma kaugsangapa tiaska tiaskakuna uiiarriska Bourdieupa.

\section{RRIMANAKUI}

Iuiarrispalla, kaugsaskapa llunchiska, iuiarrrispalla churraskakuna, sinchi iuiarriskalla, Iuiarrispalla rrurrai, Atun alpamanda runakuna, Atun uaisi iachaikudirru

Recibido el 15/05/2013

Aceptado el 15/06/2013 
La casa es un estado de alma. Incluso reproducida en su aspecto exterior, dice una intimidad.

(Bachelard, 1997: 104)

\section{Exordio}

Cada cierta mañana me percataba de su presencia, en su lugar de siempre, en esa esquina recóndita del salón de clase, esa misma donde parecían confinados todos aquellos que excedían a los otros en edad o en estatura, por lo común repitentes de curso o expulsados de otras escuelas, en últimas, los peores. No sé si tal esquina era el producto de una orquestación concienzuda de los maestros o de la aplicación implacable de alguna disposición de la inspección escolar, lo cierto es que sus ocupantes no sentían esa ubicación como un agravio, mucho menos como una marginación, sino como una suerte de licencia para quienes no esperaban nada de la escuela ni ella abrigaba nada para ellos. Tan suspendidas estaban las pretensiones de la escuela sobre esa esquina recóndita, que cualquiera que quisiera prescindir de manera temporal de los deberes escolares, fuera presentar una tarea, pasar al tablero o solo atender a la clase, pedía a los jayanes, de los modos más reverenciales, cuando no lisonjeros, una estancia finita allí donde nunca habría de llegar la mirada, ni siquiera la más indiferente o resignada, de un maestro. En esa esquina recóndita, cada cierta mañana, me percataba de su presencia, de la presencia de Raúl.

No aventuren, no supongan aún mi argumento. Solo atiendan a Raúl: él era un muchacho de pelo rubio apelmazado en cabuya, lavado en pecas, con boca normal pero dientes separados, sobre todo los paletudos de más al frente, que son los incisivos. Era flaco, de camisas cortas transparentadas de tanto pasar por el lavadero, de pantalones de terlenka bruñida incapaces de llegar a las botas, como los de saltar charcos. Como la mayoría, él no contaba con más enseres que dos cuadernos de hojas alechugadas, con forros en plástico rosado deshilachados en cada esquina, donde guardaba un lápiz al que no dudaba en sacarle punta con los dientes. A veces tenía un lapicero azul, pero con dificultad se hacía al rojo. Con tan poco recogía cuanto podía de las seis clases del día, con esa letra de contornos zurumbáticos que no respetaba margen ni cuadrícula, con esos números filudos que no guardaban proporción, todo en un interminable gris que de cuando en cuando, en una que otra hoja, soportaba el inclemente carmesí con el cual el maestro redactaba sus infaltables elegías sobre la falta de aseo, de orden, de cumplimiento. Pobre Raúl, decíamos. Pero eran elegías sin destinatario: nadie se atrevía a preguntarle a Raúl por su padre, porque él nunca lo vio, ni tampoco por su madre, a quien todos veíamos a la salida de la escuela entre esos cafetines de la cuadra vecina que en unas horas, entrada la noche, pasarían a ser puros negocios de putas.

Debo decir que de toda esa prole de jayanes condenados a la esquina recóndita, Raúl era el más socavado, no porque fuera el más incorregible de los repitentes o algún proscrito de todas las escuelas, sino porque parecía sufrir ese lugar que le cupo como destino por el simple hecho, oigan bien, de ser más alto que los otros: tenía mis ocho años, pero me llevaba muchos centímetros de más, casi tres años. Decidido a desertar del destino de los condenados del rincón, Raúl se esforzaba, cada semana, cada día, cada hora de clase, por hacer avanzar el inmenso mesón que compartía con otros tres jayanes, incluso en contra de todos ellos: aspiraba a llegar al centro de esa antigua bodega del ferrocarril convertida en aula de clase, pues era allí donde las claraboyas comenzaban a verter las luces del cielo dejando expuestos a aquellos que podían ser escrutados por la mirada que señala, que califica, que sanciona, es decir, los que podían ser educados. A esta precaria cofradía quería pertenecer Raúl, intentándolo siempre, aunque nunca lográndolo. Allí, en esa vieja bodega del ferrocarril venida en salón de clase, el iluminismo no era una abstracción de la filosofía, sino una materialidad palpable, audible, respirable, que llegaba imperfecta por entre las claraboyas, que se desplazaba en el curso del día, que no alcanzaba por igual para todos, que estaba negada para los jayanes de la esquina recóndita, entre ellos Raúl. El iluminismo era una materialidad de vez en cuando opacada por el humo intenso de los trenes que pasaban al costado de la escuela o cercenada de manera definitiva en los días de lluvia, que eran como nuestra edad media. Nunca pasó por la inteligencia de algún inspector escolar que la ilustración bien valía unos cuantos bombillos.

Todavía recuerdo la campana de la escuela: un riel colgado de un cable de acero que se tañía con alguno de los cantos rodados que tapizaba la vía inmediata. Sonaba de modo estridente, aunque costaba escucharlo entre el ruido sempiterno de las máquinas, de los rieles, de los obreros que reían y gritaban, de los cada vez más esporádicos pasajeros, de las músicas de burdel con sus endechas amorosas. Pero el tañido del riel era suficiente para que todos saliéramos al receso 
en ese patio mal cubierto de alquitrán, donde parecíamos una versión minúscula de ese proletariado que ocupaba el inmenso taller ferroviario del frente. Sí, aquí el mundo se las arreglaba sin empachos, con las formas más primitivas del poder simbólico, con los dispositivos más descalsurriados: bastaba abrir una reja para que los hijos del taller ocuparan pronto y con satisfacción el lugar de sus ancestros, tanto así que entre mis pares estaba el último descendiente de los capataces que cuidaron la trocha del naciente ferrocarril de la Sabana un siglo atrás, así como el hijo del conductor de la 1044 importada apenas unos años antes. Era este, señoras y señores, un mundo primordial, un extracto en tiempo reciente de lo que pudieron ser los últimos días de la industrialización miserabilista de los orígenes y los primeros de la industrialización benefactora que siguió después, cuando niños y niñas abandonaron por fin las factorías para ser reclutados en escuelas que, no obstante, eran próximas, casi inmediatas, casi fábricas. Pronto habría de sacudirse este mundo primordial con una auténtica desgracia, con un episodio, con un instante doloroso, que nos dejó a todos sumidos en el más pavoroso silencio.

\section{Trashumancia de los símbolos}

El tren tiene un aura que pareciera remontarlo a unos tiempos antiguos, pese a que es una invención típica, quizá la más típica, de los tiempos modernos. Es como si el tren estuviera esculpido sobre una imagen remota, casi primitiva, que sobrevive bastante escatimada en diferentes metáforas: la forma briosa, la mula de hierro, la bestia acerada. "Los trenes eran proyectiles, la metáfora exacta del destino", diría Elena Poniatowska. El afloramiento de esta imagen remota, de ese instante en el cual lo arcano del tren brota desbordando las formas modernas de la ingeniería con todas sus contenciones racionales, no está disponible siempre ni para todos: no está disponible para los pasajeros, quienes se acercan al tren cuando está detenido, domeñado, servil; tampoco está disponible para quienes lo perciben a lo lejos, en la distancia, fundido entre los paisajes repletos de vacas cagonas; no está disponible ahora para casi nadie en este país donde domina el pensamiento miserable, donde no hubo más espacio para los trenes porque se indujo al supuesto de que estos era incapaces ante las montañas, idea mentirosa, robo encubierto por tantos, que es desvirtuada, por ejemplo, por el Ferrocarril Andino, ese portento que construyera el ingeniero polaco Ernest Malinowski en el Perú a mediados del siglo XIX. Al pensamiento miserable, fértil en propuestas y yerto en proezas, no hay que pedirle nada. Su estupidez le impide poner un ladrillo sobre otro.

La imagen arcana del tren solo está disponible para quien se atreve a acercarse a la máquina cuando ella desperdiga velocidad desmandada en fuerza bruta, cuando arroja babaza grasienta entre el balasto, cuando suelta bocanadas intimidantes de humo denso y oscuro, cuando deja un calor sobre los rieles suficiente para derretir cualquier suela de zapato. Lo he visto, ha pasado cerca de mí, casi le he palpado las entrañas. Solo quien ha estado en la proximidad más próxima a un tren en plena marcha ha alcanzado a vislumbrar esa imagen arcana donde la máquina se transfigura en una mole trepidante que bufa, que desprende sudoraciones penetradas a brea profunda, que despacha truenos y centellas, que con su farola arroja una mirada ciclópea, soberbia, impenetrable: es entonces cuando la primera de las invenciones del mundo moderno se muestra como el último de todos los bárbaros del mundo antiguo. Solo quienes han vivido esta experiencia de proximidad, porque la han buscado esperando a la máquina en algún recoveco de la vía o porque se han visto sorprendidos en el paso estrecho de algún puente colgante, pueden dar testimonio de esta imagen arcana, de esta entidad desbocada, posesa. Cómo no recordar a Warburg.

Aby Warburg nació en 1866 en el seno de una familia judía de la ciudad alemana de Hamburgo. Como otros antes que él y después de él, entre ellos los teóricos críticos de Frankfurt, Warburg desistió de otros encargos de su condición burguesa para dedicarse a la vida intelectual, al estudio de la historia del arte y de la cultura. Sin duda hombre fantástico en sus concepciones, entre ellas, en aquella de la imagen superviviente, esa composición trashumante que puede por medio de los símbolos capturar un tiempo sucedido para reemprenderlo en otro: no se trata de una imagen que presentifica los símbolos solo en cuanto estos tienen de elaboración formal sino, más allá, en cuanto estos acarrean intensidad emocional, en cuanto pathos. El pathos nietzscheano que envuelve a la obra de arte. De este modo, los símbolos se entienden como depositarios de una carga cultural modelada en formas y emociones que desde lo pretérito puede encumbrar hacia el presente una fuerza que el propio presente desconoce, en capacidad de transferir creencias que por antiguas puede el ahora considerar conservadoras o que, por antiguas también, pueden transgredir cuanto ese ahora tiene por seguro: de allí, de esa fuerza simbólica que 
contiene y controvierte, deriva lo caótico, lo extático, lo racional y lo sublime del arte. En consecuencia con esto se entiende que la fuerza de una creación cualquiera no puede supeditarse solo a su tiempo, sino que en ella participan esas formas simbólicas preñadas de una intensidad emocional pretérita, a las cuales solo se puede acceder por el Pathosformel, por la evocación del pathos. Fue por esta imagen superviviente, nos dice Warburg, como el paganismo se hizo presente en el arte del renacimiento (Warburg, 2005).

Sin duda, una concepción apabullante tiene la capacidad de redimir en el pasado los principios de una fuerza que parece originada solo en el presente $y$, en eso, tiene algunas similitudes con el imaginario tal cual lo entienden autores como Gilbert Durand. Para Durand, el imaginario es una configuración simbólica donde circulan de manera simultánea "las pulsiones subjetivas y asimiladoras y las intimaciones objetivas que emanan del medio cósmico y social... El imaginario no es nada más que ese trayecto [antropológico] en el cual la representación del objeto se deja asimilar y modelar por los imperativos pulsionales del sujeto y en el cual... las representaciones subjetivas se explican 'por los acomodamientos anteriores del sujeto' al medio objetivo..." (Durand, 2004: 43-44). En este sentido, la imagen superviviente y el imaginario, cada uno a su manera y allí donde puedan concurrir, plantean la existencia de unas fuerzas subyacentes que, goteando desde el pasado por entre las fisuras de las formas racionales, modelando a estas aun cuando estas también las modelan, están en el principio de las prácticas creadoras. Esto no supone, óigase bien, una suerte de claudicación en un hálito que por arcano sería de suyo irracional: más allá, supone advertir que la racionalidad frisa en todo momento con el impulso simbólico de unas imágenes supervivientes, pero que ello no la pervierte, como supusieron Adorno y Horkheimer a propósito de la mitologización de la razón, sino que la obliga a trascender su condición de mera acción teleológica, como lo advirtieran, entre otros, Habermas y Bourdieu.

Bien puede decirse que la tragedia moderna se hace manifiesta en el momento en el cual la razón, creyendo sepultas estas fuerzas pretéritas, no las entiende vigentes, permitiéndolas entonces como entidades fantasmagóricas cuando no monstruosas que mistifican el mundo social, que imponen con ello unos ordenamientos profundos, unas jerarquías abisales, que la razón en su superficialidad toma como auténticas ontologías: la razón, engreída en sí misma, se convierte en el cobertizo de todos los modos de dominación.
La forma extrema de este racionalismo obnubilado es el colonialismo: una empresa que solo puede imponer la razón al amparo de fantasmagorías y monstruosidades denegadas, las mismas que denunciadas por el colonizado lo revisten como un ser irracional que debe ser civilizado, todo porque ve fantasmas y monstruos donde, en apariencia, solo prospera lo racional. No lejos de este racionalismo obnubilado, mejor, como su complemento, está el espiritualismo agonístico, ese que cada cierto tiempo propicia la rebelión de las deidades con la pretensión de erigirlas ad eternum contra la razón enceguecida: la razón, resignada ante el ascenso de unas entidades fantasmagóricas y monstruosas a las que considera superiores e inaccesibles, se torna abyecta, acomodaticia y cómplice. La forma extrema de este espiritualismo agonístico es el totalitarismo: una empresa que administra al mundo social con fantasmagorías y monstruosidades en capacidad de proscribir o reducir cualquier atisbo de racionalidad, esa misma racionalidad que reclamada por el subyugado hasta sus últimas consecuencias lo inculpa como un ser ausente de espíritu, extraño a la trascendencia, por lo mismo fuente de expolio, que busca razones donde lo único racional, en apariencia, son fantasmas y monstruos.

Aby Warburg murió en 1929. Cuatro años más tarde el nacionalsocialismo ascendió al poder: un proyecto demencial incubado de tiempo atrás entre los sectores más conservadores de Alemania, que pretendió una modernidad contrailustrada, soportada en esencias metafísicas cuando no en atributos mágicos, a los que consideró únicos y suficientes para reemprender las ciencias y las artes, la tecnología y la política: ideología de posesos que buscó las conquistas de la ilustración sin pasar por la razón, se apertrechó en la estética como medio expedito para capturar de una vez y para siempre las imágenes remotas, para fusionar Idee und Gestalt, para instituir en un pasado esotérico el principio eficiente del mundo, para justificar el uso indiscriminado de la violencia física exaltándola como forma superior de belleza, lo que demandó el trabajo de artistas venidos a políticos, lo que exigió un Estado gobernado por el arte. Sí, el dictador artista, dirá Michaud: Hitler nunca abandonó su pretensión de ser pintor; Dietrich Eckart, padre espiritual del Führer, era poeta y dramaturgo; Joseph Goebbels, jefe de información y propaganda del régimen, era doctor en filosofía y letras de Heidelberg y hombre de escribir novelas; Hermann Göring, ministro de la Luftwaffe, era fanático de la pintura y dedicado coleccionista; Alfred Rosenberg, ministro de los Territorios del Este, era arquitecto diplomado de las universidades de Riga y de 
Moscú; Walter Funk, ministro de Finanzas y presidente del Reichsbank, era economista y filósofo formado en las universidades de Berlín y Leipzig, apasionado por las tertulias artísticas; Joachim von Ribbentropp, ministro de Relaciones Exteriores del Reich, también noble espurio, se creía dramaturgo; Albert Speer, ministro de Armamento, era arquitecto formado en las universidades técnicas de Berlín y Münich; Ernst Röhm, jefe de la SA, componía versos a Hitler; Baldur von Schirach, jefe de las Juventudes Hitlerianas, era poeta de inclinaciones operáticas; el troglodita conocido como Julius Streicher, imaginen ustedes, se reclamaba acuarelista (Herf, 1990; Michaud, 2009). En esta plétora de artistas de talentos dudosos descansó el "romanticismo de acero" del Reich, ese que entronizó al Führer para que en él se realizaran las palabras que Novalis dirigiera en 1797 a Federico Guillermo de Prusia: "Un verdadero príncipe es el artista de los artistas; es decir, el que dirige a los artistas. Cada hombre debería ser artista. Todo puede devenir un bello arte. Los artistas son la materia del rey; su voluntad es su cincel; él educa, pone e instruye a los artistas porque solo él ve la obra en su totalidad y desde un buen punto de vista, porque solo a él le es perfectamente presente la gran Idea que debe ser ejecutada por el conjunto armonioso y convergente de las fuerzas y los pensamientos representativos" (Michaud, 2009: 62).

El delirio nacionalsocialista tomó como propia una de esas ideas fuertes que se abrió paso entre finales del siglo XIX y comienzos del siglo XX: la asociación inmediata entre imagen, movimiento y fuerza, esa que permitiría la gestión de las masas, como dijeran Le Bon y Sorel, la misma que permitiría la gestión de las máquinas, al parecer del nacionalsocialismo. Por esto, para los nazis, la ingeniería no sería más una manipulación fría y sin alma de la tecnología, sino el arte de restituir en lo tecnológico el vínculo disuelto entre naturaleza y trabajo, entre tierra y espíritu, entre sentimiento y ciencia, entre el hombre y el Geist que habitaría todo cuanto pudiera ser creado. La ingeniería debía entenderse en adelante como el oficio de un maestro constructor, creador de "objetos permanentes cósmicos, eternos y divinos" (Herf, 1990: 382; Michaud, 2009: 292-294). Esta asociación entre imagen, movimiento y fuerza sobre la cual fue erigida la ingeniería del Reich, recubrió a la máquina con un impulso vital, con una naturaleza estética e, incluso, con propiedades humanas, haciendo patente aquello que señalara Ernst Jünger: "Sí, la máquina es hermosa. Debe ser hermosa para quien ama la vida en toda su plenitud y poder... La máquina no puede ser solo un medio de producción que sirva para satisfacer nuestras necesidades materiales vulgares. Más bien, debe entregarnos satisfacciones más elevadas y profundas..." (Herf, 1990: 173-174). Pero allí donde el irracionalismo totalitario pretendió capturar de una vez y para siempre unas imágenes remotas buscando conquistar un principio eficiente para la máquina, para recubrirla con una belleza renuente a cualquier razón, para erigirla en objeto de culto del Volksgeist, sus víctimas no vieron sino la cruda concreción de las peores fantasmagorías, de las monstruosidades más viles: el tren, uno de los frutos primeros de la revolución industrial, la invención típica de los tiempos modernos, que emancipara a tantos del presidio del origen, de la aldea elemental, fue raptado por el nacionalsocialismo para que habitara en una imagen primordial única, brutal y aterradora, la de la bestia devoradora de hombres: las máquinas del Reichsbahn que transportaron a millones a la muerte en los campos de concentración.

El irracionalismo reduce la fuerza a un sentido único y confisca la imagen a una expresión mínima: la violencia física. Pero el tren, su feroz estampado en movimiento, su rugido imponente de cascada, también ha sido portador de alegrías infinitas, de mensajes de esperanza, de optimismos: así como en trenes fueron llevados cientos de miles a campos de concentración, también en trenes muchos lograron huir, encontrar refugio. Pienso, por ejemplo, en las travesías checoslovacas, en esos itinerarios orquestados por Nicholas Wiston para salvar a cientos de niños judíos de las manos de los nazis. Pero pienso también en cuestiones más elementales, más próximas: en los rostros alegres que aparecen por las ventanas una vez el tren encalla entre estaciones; también en los rostros ansiosos de quienes esperan locomotoras y vagones, seguros de que estos les regresarán algo por mucho tiempo perdido; están los rostros melancólicos de quienes saben que nunca más volverá el tren con nadie a quien esperar, tampoco con noticias importantes. Quizá los elementos que componen las imágenes modernas del tren sean muy próximos a aquellos con los cuales las gentes de otros tiempos entendieron las deidades encargadas del destino, fueran moiras o fatas: hileras, tejidos, agujas, horas, nacimiento, muerte. Quizá, habrá que indagarlo, el tren transita por nuestra cuenca semántica, por el cauce histórico-social que denominamos modernidad, con los últimos bártulos que dejó la caída de los titanes: fuego, humo, hierro, ruido. Sin duda el imaginario en sus cuencas semánticas, las comprensiones potamológicas de lo profundo, son un asunto de una hermosísima complejidad, por lo menos cuando lo imaginario no se entiende como cualquier cosa ni se deja atrapar 

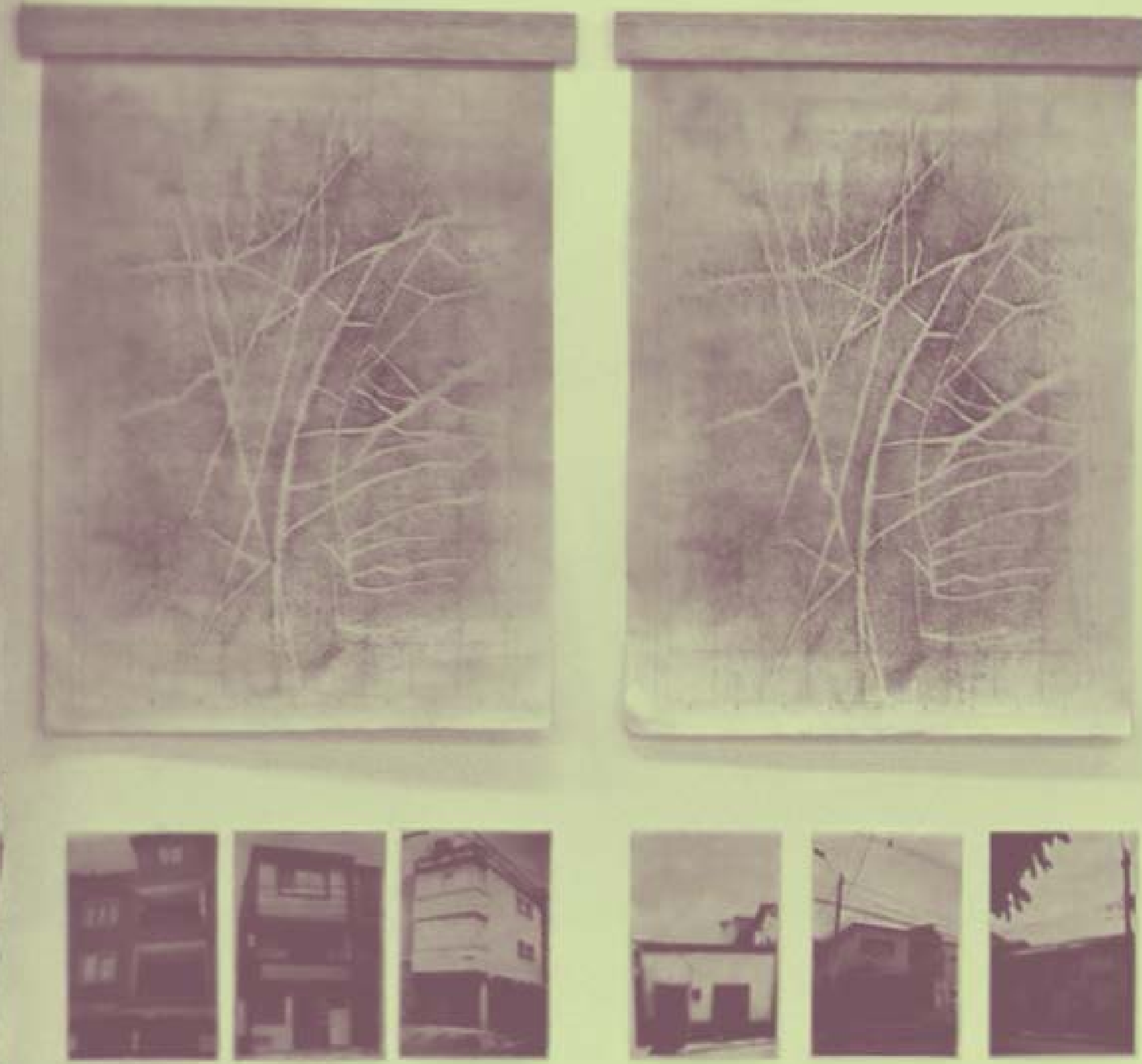
de manera escuálida por las filosofías de la conciencia (Durand 1994 y 2004).

Al medio día, luego del tañido último del riel que fungía como campana, hordas de bribones se lanzaban presurosas a las calles inmediatas a la escuela a fregar como tábanos. Algunos escueleros se confundían entre los cada vez más menguados pasajeros de la estación, entre las gentes cargadas con valijas y bultos que no había que dudar iban para tierra caliente; otros escueleros entraban a los cafetines y a las tiendas próximas, que para entonces tenían los orinales limpios, olorosos a lavanda barata mezclada con miados del día anterior; otros más, la mayoría, empezaban a caminar sobre los rieles, a hacer juegos de equilibrio so pena de puño y patada, hasta encontrar, uno o dos kilómetros más adelante, la casa huérfana sobre la vía o quizá un barrio completo hecho para ferroviarios o sus descendientes. De cuando en cuando los equilibristas debían abandonar la vía porque venía algún tren, alguna máquina, de seguro en un trote cansino, que luego de su paso dejaba un silencio lastimero, apenas perturbado por el ruido de los zapatos entre las piedras o por alguna pieza de metal cayendo allá en el taller cada vez más solo, cada vez más abandonado. Y consecuente con el acabose del mundo, todos aquellos escueleros que compartíamos trayecto, callábamos con cierta solemnidad. Mientras tanto, a lo lejos, entre la maleza, sepultados por el sopor del medio día, los trabajadores del ferrocarril parecían durmientes, abatidos: estaban iniciando una huelga, una más. Sería la última.

\section{Más allá del racionalismo y la sensibilidad}

Muchos asumieron que el mundo moderno estaba en una crisis profunda, aunque los libros que los enteraron del asunto nunca fueron precisos en el dónde, en el cuándo, en el por qué de todo esto: de las teorías marxistas a las posestructurales, de Adorno a Habermas, de Nietzsche a Foucault, de Bell a Fukuyama, de Marcuse a Lyotard, irrumpió un espectro de razones y circunstancias al respecto, cada una con sus variantes y matices. De hecho, algunas razones y circunstancias resultaron propicias para que fueran aventurados toda suerte de nombres rimbombantes que cautivaron sin menor esfuerzo a tirios y troyanos: fin de la historia, de las ideologías, de los grandes relatos. Sociedad posindustrial, posmodernidad, poshumanismo. Todos los "pos". Aunque esta crisis se definió de carácter estructural y de naturaleza global, se hicieron frecuentes los lugares comunes, los discursos manidos, las reflexiones iterativas, siempre recayendo en los mismos tópicos, a propósito de los mismos fenómenos, con los mismos autores infaltables, como si el mundo moderno pudiese entrar en crisis de una vez y para siempre y de la misma forma en un continente, en un país, en una provincia, en una ciudad, en un poblado, en un barrio, en una calle, en una casa. Luego de leer y releer razones, muchas profundas y sinceras, otras impostadas y banales, concluí que es difícil que alguien puede entender esta tal crisis si no ha sido testigo de los avatares de las empresas de la modernidad: entiéndase testigo, dicho de otro modo, en cuerpo presente, piel abierta y ojos vista. Sí, de las empresas de la modernidad: un hospital, una escuela, un teatro, un museo, una fábrica, un ferrocarril.

El universo académico, que depende de cierta suspensión de la inminencia del mundo social para hacerse a este mundo de modo eminente, es decir, privilegiado, tiende por ello a confiscar las experiencias inmediatas de los académicos para sustituirlas o reemplazarlas por nombres, por lenguajes, por discursos, por sentencias, por teorías, por paradigmas. En algunas circunstancias, como aquellas en las cuales las posiciones académicas están ocupadas por hijos de clase trabajadora ascendidos a pequeña burguesía, esta confiscación de las experiencias inmediatas corre al mismo tiempo como una abrasión radical de las inmediateces de la clase de origen, un distanciamiento con aquello que haría al académico objeto de la cultura de la que él se pretende solo sujeto. Confiscación de lo inmediato y abrasión del origen solo son posibles con la recurrencia excesiva al concepto y a la manera, con el abuso de la jerga y de la pose, que no son otra cosa que la exacerbación de la censura que debe autoimponerse el recién ascendido para custodiar el cuerpo y el lenguaje, para cuidar aquello que viniendo de las entrañas del origen puede prorrumpir sin permisos ni consentimientos para delatar la escasa antigüedad de algo que se pretende remoto: gente posuda, gente tozuda dicen por ahí. También decía por ahí Bourdieu: “El pequeño burgués es un proletario que se empequeñece para llegar a ser burgués... El pequeño burgués es un burgués que vive con pequeñez" (Bourdieu, 1974: 25). La claudicación de la experiencia inmediata que le es impuesta al académico, tanto más en condiciones de subordinación académica y de colonialismo intelectual, conduce a que asuma que toda relación con el mundo social solo pueda ser intelectiva y de un tipo de intelección reducida a racionalismo cerrado. Sobre estas mismas convicciones se asume que cualquier trance que enfrente el mundo social deba ser asumido con un criterio pedagógico, 
entendiendo la pedagogía como un dispositivo de racionalización e intelectualización. Esta concepción pedagógica, por ejemplo, es ajena a las concepciones fantásticas de Aby Warburg; esta pedagogía no tiene idea del imaginario.

Con el paso de los días el inmenso taller se fue haciendo más silencioso, casi yerto. La maleza empezó a crecer incontenible, ocupando sin remilgos los remaches, asumiendo con impostura, pero sin vergüenza, el lugar que otrora fuera de las tuercas y los tornillos. Los grandes ventanales que ofrecían luz generosa a la inmensa planta fueron cayendo uno a uno, destrozados por los vientos de la desidia. Las máquinas que llegaron a reparación quedaron desarmadas en cada una de sus partes, todas ellas esparcidas cual vísceras de res en el estante del carnicero. La reja que encerraba el lugar pasó del gris reluciente a un rojo aplacado, a un óxido rumboso, que para cualquier aficionado a las máquinas es el color del desamor, de la indiferencia, de la apatía. "iNo quiero recordarte, te dejo en el oxido!", grito la novia al maquinista, o eso fue lo que él oyó, en los días aquellos en que todo estaba perdido, hasta el amor. Las escasas locomotoras que todavía andaban por ahí, cada vez más débiles, cada vez más rengas, entraban al taller medio moribundas, sin vagones de carga, mucho menos de pasajeros. El mundo que teníamos enfrente entraba en una franca desaceleración, como si alguien le estuviera extrayendo las sustancias a la velocidad o las fibras al tiempo: no había velocidad ni tiempo inicial, solo finales. Si por lo menos estuviera conmigo Ángela Petrus.

Pronto dejamos de avistar el furgoncito en forma de ambulancia en el que estábamos seguros que llegaban de manera puntual, casi religiosa, las quincenas de los trabajadores del ferrocarril. Con la ruina del tren llegó también la pobreza. Un desafío a una comunidad de barrios bastante integrada, cuyos miembros tenían orígenes regionales comunes, trayectorias compartidas, cargos y encargos próximos y parentescos de sangre o políticos. Una comunidad agraciada, con una apertura desmedida incluso con aquellos que, como nosotros, como mi familia, éramos ajenos a la empresa, aunque teníamos ancestros y próximos en ella. Pero la plata se fue haciendo escasa, las deudas más amplias, los compromisos más incumplibles, las tiendas más renuentes al fiado, las gentes más cautas en la solidaridad, la rabia más incontenible ante el pagador que contra su nombre nunca pagaba. El mundo parecía retroceder varias décadas, otros dirán que siglos, todo porque en esta comunidad los vínculos parecían desatarse a tal ritmo que pareciera inevitable caer de nuevo en alguna rapiña original, como aquella que existiera antes del monstruo hobbesiano. Mientras tanto, el gobierno buscaba la extinción definitiva de la empresa prometiendo gruesas indemnizaciones. Era el ocaso de un mundo primordial, el cual creí por mucho tiempo único e irrepetible, pero que habría de encontrarlo años después en otros lugares, en otros pueblos, en otras provincias, en otras regiones, donde también el tren fue haciéndose viejo y moribundo, arruinando los talleres, socavando a los trabajadores, quebrando la solidaridad entre las gentes, exacerbando rencillas, permitiendo, cómo no, la aparición de la brujería y la hechicería como mecanismos reguladores de las relaciones sociales, de modo semejante, pero no tan exagerado, como entre los azande, tal cual lo consignara Evans-Pritchard (1976) en la que fuera una de mis lecturas preferidas en mis tiempos de estudiante de antropología.

\section{La sagrada majestad del estado}

Los trenes se entregaban a la muerte sin garbo, sin un bufido. Las estampas lastimeras del acabose contrastaban con las alborozadas del nacimiento, que sucediera por allá en julio de 1882. Hay que ver lo que fue eso, la concurrencia, la algarabía, la prestancia de los testigos. Alfredo Greñas dejó una estampa memorable de esa ocasión, a la que puso por nombre "Ferrocarril de la Sabana. Inauguración de los trabajos": arriba, tutelando la estampa, el frontis de una locomotora iluminada por un sol alboreo; al lado un retrato del general Daniel Aldana, un hombre decimonónico, que en colombiano quiere decir dedicado a componer constituciones y a combatir en guerras civiles, el mismo que en el asueto entre refriegas ejerció como gobernador del Estado de Cundinamarca. Fue entonces, como gobernador, que Aldana se dedicó con alma, vida y sombrero a impulsar el ferrocarril de la Sabana. En la parte media de la estampa de Greñas están las gentes que atiborraron la plaza del pueblo en ese día de inauguraciones, mientras en el fondo, tímida pero evidente, se dibuja la modesta iglesia con su espadaña como de templo doctrinero. En la parte más baja de la estampa, como por entre breñas, se alza una panorámica del valle de Corito, también un jinete y dos paisanos, que por más esfuerzos no identifico, aunque uno de ellos se parece a Núñez, quien siendo liberal fue amigo de Aldana, pero que luego conservador puso al "Indio", que así le decían al general, con pies en polvorosa hacia el exilio. 


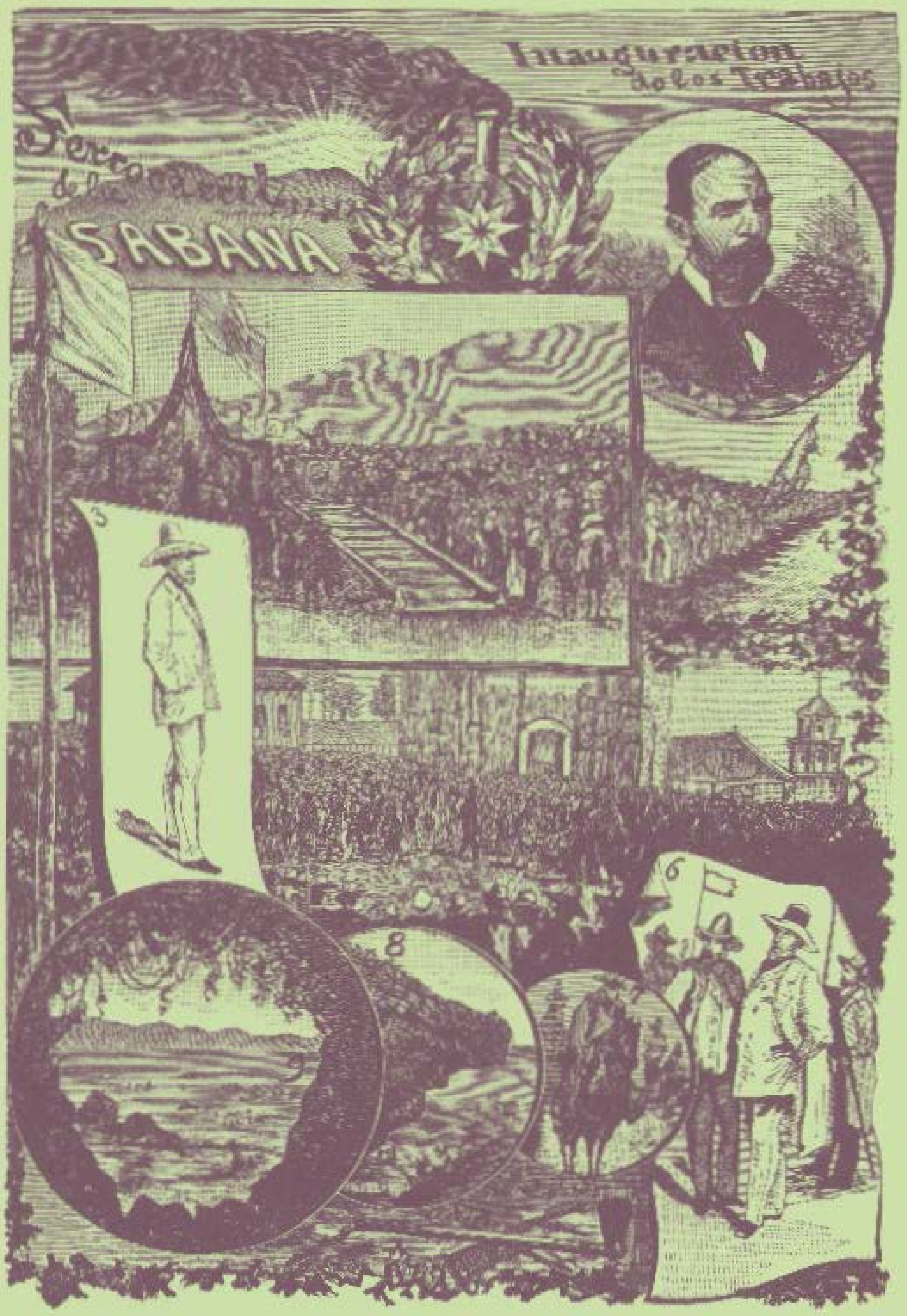


Un siglo más tarde todo exhalaba ruina: la estación caída a pedazos, con puertas que uno sabía cerradas para siempre, con ventanas sepultadas en el gris profundo del polvo, con unos muros corroídos donde pendían en hilachas los carteles algo jechos de la última gesta electoral de Consuelo de Montejo, quizá luego de sobrevivir a la persecución del bellaco del Turbay. Los pasillos inmediatos, por donde debieron circular tantas gentes en procura de acomodación o de tiquete, estaban supurados por las heces, por la mierda de mendigos y borrachos, por los miados de los siempre incontinentes paisanos, arrasado el brillo de ese piso de tabletas rojas con bordes blancos. En algún momento había una reja, más allá una cadena con un candado, como esos que se ponen para desahuciar un lugar hasta la eternidad. Inmediato a la estación, pasando la carrera primera, estaba el famoso pasaje, una calleja tan propia de las ciudades con trenes, pensada para alojar cierto comercio peculiar con ínfulas de antiguo bazar parisino, pero que ahora apenas resguardaba algún cafetín peligroso, un consultorio médico, una sombrerería y toda la tristeza que podía caber en la existencia más triste. Aguantar la lluvia debajo de algún alero del pasaje en estos años mustios era el rito propiciatorio para cualquier suicidio. Al frente de esta orgía de ruindades, participando de ellas, siendo como ellas, una escuela, el salón de Raúl que era también el mío, el riel colgado de un cable. La estación del ferrocarril, esta como las tantas que hubo hasta Girardot o Santa Marta, eran la expresión de la incapacidad de un Estado capturado por toda suerte de alimañas.

Las vías férreas fueron el primer proyecto moderno para articular de manera eficiente los Estados, los territorios, las poblaciones: a nivel nacional este proyecto fue delegado a los ferrocarriles, mientras a nivel local, en las ciudades, le fue encomendado a los subterráneos, a los metros y a los tranvías. Los países y las ciudades que acometieron esta tarea desde mediados del siglo XIX consiguieron en el curso de las décadas crear espacios comunes, relaciones compartidas entre sus habitantes, incluidas las de dominación, que demandaron esfuerzos denodados de diferentes agencias por naturalizar la vida entre extraños coexistentes, que sería la vida de ciudadanos entre ciudadanos. Los países y las ciudades que acometieron de manera tardía esta tarea o que nunca la acometieron, fue porque perseveraron en la administración del mundo social con base en identidades primordiales, de suyo confinadas y excluyentes, esas soportadas en las supuestas ascendencias de la sangre, del apellido, de la casta, del estamento, en últimas identidades que descansan en asepsias seminales, que llevan a que las gentes se ofendan menos cuando se les acusa de malos ciudadanos, algo que en realidad no les dice nada, que cuando se les dice que son unos auténticos hijueputas, que en apariencia les dice todo, incluso cuando no es cierto. En estos países, en estas sociedades, el proyecto de construcción nacional quedó supeditado al lomo de mula, a la carreta miserable, al camino intransitable, que permitieron que en cada lugar prosperaran minúsculas aldeas cada una con su señorío, cada una con sus siervos y esclavos. De hecho, cuando lleguen los trenes a estas sociedades, no podrán revertir el estamentalismo cerril, sino que por medio de ellos, de las calidades de sus locomotoras, de los estilos de sus diferentes vagones, se podrá oficializar con impudicia la condición social de los pasajeros como inmanencia misma de la condición ciudadana: pasajeros y ciudadanos de primera, de segunda, de tercera, de cuarta categoría. Así, de este modo, terminamos en la avenida Colón lo que empezamos en Angosturas, poniendo al tren a mover a una sociedad inamovible, un capítulo más para esa ética y cinética del movimiento de la que hablara Castro-Gómez (2009).

El surgimiento de un espacio de coexistencia entre extraños, de quienes reclinan sus identidades primordiales a la esfera privada en beneficio de una identidad ciudadana que debe copar la esfera pública, supone una reacomodación estructural del mundo social. Pero no se trata de esas reacomodaciones auspiciadas por medio de disposiciones, reformas, reglamentos y leyes, que siendo solo las formas últimas que adquieren las dinámicas sociales son tomados por los espíritus ingenuos o mañosos como los principios primeros de la existencia del mundo social: un sesgo de quienes asumen la juridificación del mundo como principio ontológico de lo social, que no es sino una expresión más de esa colonización interna del mundo de la vida que pretende capturar, imponer y circunscribir en el derecho y para el derecho las derivas procedentes de los modos de configuración de lo social y de los simbolismos que esto moviliza (Habermas, 2010: 882-904). Sin duda una artimaña oportuna para todos los totalitarismos, porque puede convertir en naturaleza lo que solo es ley para, desde allí, sacar a la ley de la ley misma, de tal suerte que quien atente contra ella pueda ser acusado de actuar contra natura, que es siempre la acusación que profieren y prefieren los tiranos. Ante esto, para entender la profundidad de la reacomodación estructural que está en la base de lo ciudadano, habría que interrogar los principios de la majestad del Estado, de aquello que lo torna omnipresente y en presunción invisible, una aproximación que implica pisar 
en terreno de lo sagrado. Es allí, en este terreno, donde podemos explorar las relaciones del Estado, la ciudadanía y el arte más allá de cualquier instrumentalismo y racionalismo cerrado.

Decía Durkheim: “El dios del clan, el principio totémico, no puede ser otra cosa que el clan mismo, pero hipostasiado y representado en la imaginación bajo las especies sensibles del vegetal o el animal que sirve de tótem" (2007: 329). En otros términos, Dios no es otra cosa que la sociedad que se sacraliza a sí misma o, si se quiere, Dios es el recurso que tienen los individuos en asociación para objetivar las fuerzas que organizan su existencia y que son, en toda situación y circunstancia, fuerzas sociales. Sobre este principio exquisito en implicaciones, Durkheim advertía que las acciones, prácticas, relaciones y formas de organización sociales, por el hecho de ser eso, sociales, deben a ello una fuerza que está más allá de la conciencia individual, que está emplazada en la conciencia colectiva con un aire tal de exterioridad que puede encarnar como una entidad absoluta con potestades sobrenaturales. Esta fuerza surgida del socius pero que niega al socius como fuerza, más aún, esta fuerza surgida del socius pero que debe a la denegación del socius su naturaleza misma como fuerza, no es otra cosa que el principio eficiente de lo sagrado: una fuerza surgida de una trama social que no puede ser confundida con la trama misma que debe ser denegada para que la fuerza exista. En el intersticio entre la trama y la fuerza la ciencia social durkheimiana instalará la coacción y la representación, la ciencia weberiana ubicará la racionalización y la legitimación y la ciencia marxista, desde Lukács hasta Adorno, emplazará la fetichización y la enajenación. Entreveradas entre estas ciencias, discurriendo o escapando de ellas, estarán las miradas más recientes, desde Foucault hasta Bourdieu, que interpondrán al poder, a la episteme, a la creencia. Por cualquiera de estos senderos se llega de manera diferente al terreno de lo sagrado.

Una vez acá, en el terreno de lo sagrado, cambia la mirada sobre la cuestión del Estado, dominada en lo habitual por concepciones contractuales y normativas. Entonces se puede intuir que el Estado surge allí donde escalan de tal manera las relaciones sociales que se produce una fuerza sobre la cual se configura, legitima e incluso naturaliza todo un entramado de instituciones: siendo así, se puede ubicar el origen del Estado moderno en el momento en el cual las relaciones sociales que entrometen la violencia (imposición), la tasación (medición), la tributación (dación) y la titulación (delegación), otrora feudalizadas en señoríos al tamaño de cada señor, progresan en una intensidad tal que pueden cristalizar unas burocracias que, entronizadas por el monarca con el revestimiento de una nueva nobleza, están en capacidad de consagrar y consagrarse al gobierno, es decir, están dispuestas a subsumir la fuerza derivada del socius, negando al socius, dentro de la fuerza del monarca mismo, que es de suyo, por una dignidad que pareciera fuera de las atribuciones de los hombres, una fuerza sagrada (Kantorowicz, 1985; Bourdieu, 1989 y 1994; Weber 1997 y 2005; Elias 1997). Por esto, a todo Estado moderno, incluso al surgido del regicidio, o sobre todo al surgido del regicidio, le subyace la imagen remota de un príncipe soberano, de un rey con su fasto, que, como la imagen arcana del tren, no está disponible siempre ni para todos, pero que cuando brota en un instante puede resultar tremenda, a veces aterradora, a veces enloquecedora como cuando ella se manifiesta al tirano, que en cualquier circunstancia o bajo distinto credo, siempre será un orate. En últimas, el Estado surge de las relaciones sociales pero está por fuera de las relaciones sociales, es una fuerza de suyo social que solo puede existir en tanto pueda denegar lo social que lo hace una fuerza y que por esa denegación, pues es por ella, se erige en fuerza sagrada. Para Taussig, este es el principio del fetichismo del Estado, con E mayúscula dirá él, que oculta su origen social, que lo impone sobre lo político: por esto mismo el Estado, como el tótem, está rodeado de prohibiciones, está guardado de manera celosa de cualquier representación que pretenda develarlo; de hecho, el Estado solo puede salir de sus opacidades por las artes del maleficio y de la fantasía, esas que "hacen surgir el resplandor sagrado de lo secular" (Taussig, 1995). Hay algo de maleficio, también de fantasía, en el Hobbes que hace visible al Estado cual Leviathan y en el Neumann que lo denuncia cual Behemoth, el más monstruoso de los monstruos, el Estado nacionalsocialista.

Más allá de cualquier mistificación, el retorno al terreno de lo sagrado permite superar el anquilosamiento de las concepciones ideológicas e ideologizantes que suponen que el papel del Estado en el mundo social se reduce a propiciar un inmenso engaño colectivo en beneficio solo del poder y de la mercancía que, con esto, son entronizadas como las mediaciones exclusivas entre la fuerza y la trama social, entre el sistema y el mundo de la vida. Si se quiere, la restitución del Estado como fuerza social denegada que como tal es sagrada, que se expande al extremo de constituirse en horizonte omnicomprensivo, permite incorporar como mediaciones determinantes a la cultura y al lenguaje y, 
con ellos, a las acciones, a las prácticas y, en general, al mundo de la vida. Entonces, una vez con el Estado en el terreno de lo sagrado, que lo involucra no solo con el poder y la mercancía sino también con la cultura y el lenguaje, el fetichismo puede ser interpelado en su acepción original, esto es, como la práctica en capacidad de dotar con espíritu a las cosas sin espíritu, asunto que en la tradición occidental hunde sus raíces en la creación misma del hombre por efecto del soplo divino: "Yahvé Dios formó al hombre con polvo del suelo, e insufló en sus narices aliento de vida, y resultó el hombre un ser viviente" (Génesis 2, 7). Detrás del fetichismo, dirá Taussig, está "una historia europea de la conciencia que se configura a través de la formación de objetos y supone una compulsión por fusionar y separar y volver a fusionar al creador con la creación y la cosa creada..." (Taussig, 1995: 153). La interpelación del fetichismo en su acepción original permite inquirirlo en las mercancías, pero también en los códigos jurídicos, en los bienes simbólicos, en el Estado mismo, en toda creatura creada por la creatura (Bourdieu, 1999; Adorno y Horkheimer, 2007; Foucault, 2007; Habermas 2010; Gartman 2013).

Así entendido, el fetichismo se despliega como principio religioso, práctica hechicera, cuestión teológica, fuente de valor e inclusive premisa científica, como en el caso del positivismo. De hecho, fue desde las profundidades que frisan lo mágico y lo religioso desde donde Marx extrajo al fetichismo, sabiendo como sabía que cualquier análisis crítico del capitalismo pasaba por trascender la economía política desnudando en el racionalismo de sus premisas, en la instrumentalización de su práctica y en la ensoberbecida solvencia moral de sus presupuestos, la existencia de un inconsciente deshabilitado, cuasi secreto pero poderoso, que enmascaraba los principios de la acumulación, la génesis de la riqueza y la historia del expolio. Esto llevó a Dussel a señalar que Marx fue ante todo un teólogo, algo en lo que resultó definitivo su origen en una familia judía, su proximidad con el rabinismo, su propia formación inicial como maestro de teología y su tránsito por esa gran construcción teológica del siglo XIX que fue el hegelianismo y que le permitió al joven Marx encontrarse con la filosofía de la religión de Feuerbach. Dirá Dussel: “Marx realiza, en sentido estricto, una crítica religiosa de la economía política, es decir, descubre los mecanismos de dominación del capitalismo como estructuras fetichistas, demoniacas, satánicas, idolátricas" (Dussel, 1993: 127-128). El trasunto teológico de Marx ha sido cuestión sustancial para las posturas más lúcidas del marxismo, renuentes al instrumentalismo vulgar de cualquier pensamiento y advertidas de los terribles peligros que esta instrumentalización conlleva, sabidas ellas que aguas hay entre entender lo sagrado y creer en lo religioso y que, de cualquier forma, lo uno y lo otro son creaciones humanas. Es el hombre el que crea a Dios y no Dios el que crea al hombre.

De nuevo al reposo, a la imagen arcana que gotea por entre estructuras, incluidas las sagradas, entre ellas el Estado. Sí, se escucha como un grifo mal cerrado perdido en medio de la oscuridad. Entonces se dibujan unos vínculos entre el arte y el gobierno, entre la estética y la política, entre el creador y el Estado, que son vertebrales pero no evidentes, de ninguna manera inmediatos, mucho menos de causa y efecto, como lo creyera el dictador artista: "los símbolos son velos tendidos sobre lo sagrado para incitar a adivinar el secreto", decía Klibansky a propósito de los esfuerzos acometidos por tantos intérpretes alrededor de la Melancolía I de Durero (Klibansky, Panofsky y Saxl, 2012: 19). Como lo advirtiera Taussig, el arte tiene la potestad de asistir al instante en el cual la imagen arcana merodea al tótem, que es el mismo instante en el cual el tótem se impone sobre la imagen arcana para guarecer la representación de aquello que no puede ser representado sino por imagen interpuesta, próxima en todo caso, como esas especies sensibles del vegetal o el animal a las que aludiera Durkheim. Ese instante también es el mismo en el cual la trama social se desgarra de su propia fuerza para luego inclinarse reverente ante ese, que es su desgarramiento, cual si fuera una exterioridad extraña. Más aún, es el cataclismo de las placas que se mueven en el momento en que la sociedad objetiva su propia fuerza, el que permite las hiancias por donde gotea la imagen arcana para merodear al tótem. El arte, hace miles de años como ahora, queda emplazado en medio de ese episodio primitivo de la fuerza redimida y la imagen revenida, acontecimiento al que puede revestir como una renuncia o un expolio del socius por el socius, o como una invención del socius por efecto de lo sagrado que pareciera entonces precederle: de allí le viene al arte una especie de condición huérfana, de orfandad, como si fuera un sobreviviente de ese mundo que existía antes de cualquier renuncia o expolio, en capacidad de denunciar en la dación del socius la génesis de lo sagrado; pero también de allí le viene al arte una especie de condición privilegiada, un don, que procedería de su carácter de testigo excepcional de ese acontecimiento en el cual lo sagrado hace a los individuos, los vincula, los asocia. 

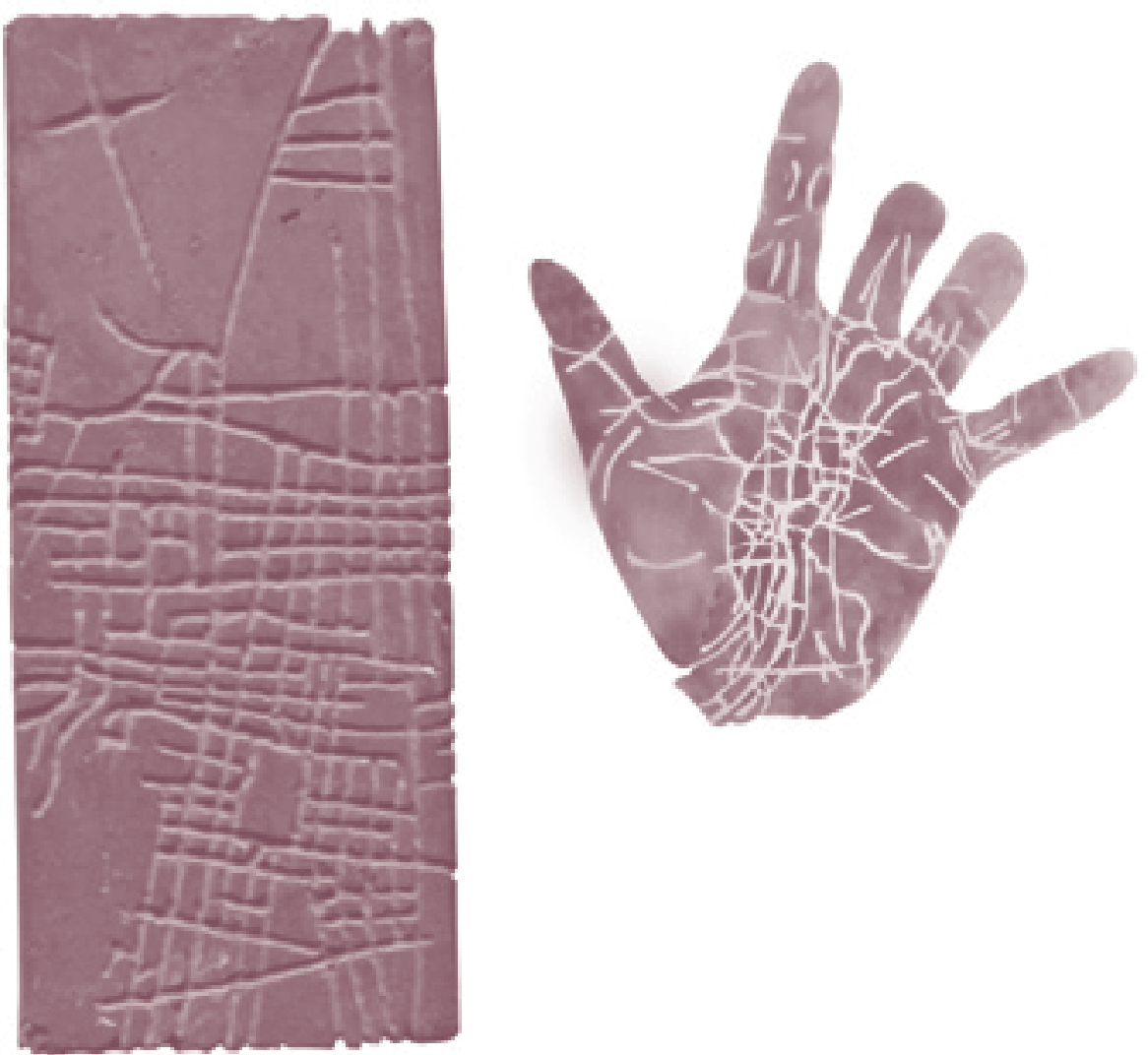

< Geomancia 2, José Julián Agudelo, 2009

Si no fuera porque tenían un tablero, los salones serían simples bodegas del ferrocarril llenas de pupitres, y entre semana, de lunes a viernes, pero solo hasta las doce y cuarto del día, también llenas de niños, que no de niñas, porque para ellas había otros lugares donde instruirlas. Los símbolos en la escuela eran escasos, si al caso una bandera y un escudo del departamento de Cundinamarca en la oficina del director. Obvio que había una bandera de Colombia, como esas que repartió el Ministerio de Educación Nacional para algún festejo patriótico importante, aunque nunca se desempacó porque en el tiempo que estuve no fuimos a desfiles ni a procesiones. También había una placa en piedra en la pared principal de la escuela, con el nombre grabado de nuestro mentor, un antiguo presidente del sindicato de trabajadores ferroviarios, quien había fallecido no sabría decir cuándo, aunque supuse por la cierta solemnidad y la limpieza de la losa que su cuerpo moraba entre nosotros: a diferencia de muchos niños de ocho años, quizá menos estúpidos, tenía la idea que debajo de cada placa, de cada busto, de cada estatua con nombre desconocido, había un muerto sepultado, porque los monumentos eran cosas concernidas con los muertos. La nuestra era una escuela por fuerza de los uniformes, de la gritería sin sentido, del olor a saco de lana verde usado a diario, de los regaños de los profesores embejucados por el problema de la multiplicación y la división, pero no era una escuela por la arquitectura, por sus diseños panópticos, por sus simbolismos explícitos o implícitos, que en una bodega del ferrocarril se reducían a un letrero refundido en una esquina que decía "LT WT 24.000". Días dediqué a descifrar esas iniciales, pensamientos sacrificados en detrimento de cosas no sé si más útiles, pero cuando menos más urgentes. Todo hacía que la escuela quedara camuflada entre trenes y talleres, invisibles sus estudiantes.

\section{La alegoría y el arte consagratorio}

Por medio de la fuerza y de la imagen se aventura un vínculo entre el Estado y el arte que anda por senderos ajenos a ese racionalismo cerrado que solo entromete entre uno y otro la acción de medios a fines, una razón de utilidad y utilitaria, apenas superficial, siempre preñada con la idea de lo ideológico, donde lo único que cabe es el uso dócil o la exclusión mutua, que desconoce lo que debe la fuerza del Estado a la explotación de la imagen arcana y lo que tiene el arte de la fuerza primitiva que es sagrada. En este paraje de la fuerza y de la imagen también es posible pensar en una reflexión sobre el mundo social y la ciudadanía 
lejana de esos discursos manidos, derivados de esta razón inmediatista, también instrumental, que suponen que la ciudadanía es de suyo un objeto normativo, que eso mismo la hace por naturaleza un objeto formativo, que se debe interiorizar en los individuos por medio de rutinas jartas en valores cuando no en cursos y cursos cada uno más requisito que el anterior, que además tienden a orientarse ante todo a los más pobres, a los considerados vulnerables, pues se cree que ellos no participan de la ciudadanía por culpa de su propia ignorancia cuando no de su mera inconsciencia. Lo más sorprendente es que pretendemos que una cuestión que compromete dimensiones existenciarias, como es la vida compartida con extraños, pueda atenderse con semejante concepción de ciudadanía, que es esclerótica hasta los tuétanos, que es risible e irrisoria si se la utiliza como libreto en este teatro de catástrofes que es nuestra democracia. Nada sucederá con la ciudadanía si se la mantiene alojada en el "conscientismo" de los inagotables catecismos cívicos reciclados de cuando en cuando y, sobre todo, de los profesores de todas las asignaturas, quienes, dispuestos de modo obediente al mundo social por efectos de la escuela -valga decir, ellos más que nadie-, creen por lo mismo que toda disposición en el mundo social solo puede ser producto exclusivo de la obediencia escolar.

Un lugar sugerente para indagar la confluencia de la fuerza y de la imagen es la alegoría o, de manera más explícita, la composición alegórica. Decía Durand que existen distintos modos de hacerse al mundo, unos directos, en los cuales las cosas con sus imágenes están disponibles de manera inmediata e inminente incluso sin pretenderlas, y otros indirectos, en los cuales cosas e imágenes no están disponibles o en los cuales de las cosas solo están disponibles las imágenes. Así, en unos casos, estamos ante un signo en el cual significante y significado están en una relación próxima, indicativa y arbitraria, asunto semiótico, mientras en otros casos estamos ante un signo en el cual significante y significado están en una relación distante, no indicativa y no arbitraria, asunto simbólico. Ahora, dirá Durand, en las situaciones en las cuales el significado apenas indica algo del significante, cuando el primero solo puede ser la traducción del segundo, el signo será alegórico; en las situaciones en las cuales entre el significante y el significado se instala una bruma que agota cualquier indicación o traducción, donde solo puede haber una transfiguración, el signo será, en estricto sentido, simbólico. Por tanto se puede afirmar que los signos alegóricos están a medio camino entre los signos arbitrarios "que remiten a una realidad significada que, aunque no esté presente, por lo menos es posible presentar", y los signos simbólicos "que valen por sí mismos". Así, mientras "la alegoría es la traducción concreta de una idea difícil de captar o expresar en forma simple" y, por tanto, "los signos alegóricos contienen siempre un elemento concreto o ejemplar del significado", "la imagen simbólica es transfiguración de una representación concreta con un sentido totalmente abstracto", esto toda vez que "el símbolo es... una representación que hace aparecer un sentido secreto; es la epifanía de un misterio" (Durand, 2000: 12 y 15, resaltados en el original). En últimas, las formas simbólicas orbitan entre lo sígnico, lo alegórico y lo simbólico que suponen a su vez distintas relaciones entre las cosas y las imágenes, entre significantes y significados.

Bourdieu señalaba que mientras unas tradiciones se orientaron a interrogar a las formas simbólicas en cuanto tienen de actividad productiva de la conciencia, esto es, en cuanto estructuras estructurantes, lo que puso el acento en el modus operandi, otras tradiciones se orientaron a interrogar a las formas simbólicas en procura de sus estructuras inmanentes, esto es, en cuanto estructuras estructuradas, lo que puso el acento en el opus operatum. Bourdieu también señalaba que mientras unas tradiciones condujeron la cuestión de las formas simbólicas a las funciones gnoseológicas, otras tradiciones lo hicieron hacia sus funciones histórico-sociales y, más allá, hacia sus funciones políticas, esto es, a las formas simbólicas como instrumentos de dominación. En medio de estas distinciones se instaló el salto que acometió Bourdieu al poner en concurrencia a Marx, Durkheim y Weber, pero también a Mauss, LéviStrauss y Panofsky, lo que le permitió restituir los tránsitos entre el opus operatum y el modus operandi, entre lo gnoseológico, lo social y lo político, que son atribuciones del poder simbólico, que es, en efecto, "un poder de construcción de la realidad que tiende a establecer un orden gnoseológico...". Para Bourdieu, "los símbolos son los instrumentos por excelencia de la 'integración social": en tanto que instrumentos de conocimiento y de comunicación (cf. el análisis durkheimiano de la fiesta), ellos permiten el consensus sobre el sentido del mundo social, que contribuye de modo fundamental a la reproducción del orden social; la integración 'lógica' es la condición de la integración 'moral'..." (Bourdieu, 1977: 407-408, resaltado en el original). En últimas, la economía de las formas simbólicas tal cual la entiende Bourdieu restituye los vínculos entre las estructuras gnoseológicas y las estructuras de dominación. 
Así entendida, la economía de las formas simbólicas permite interrogar a la composición alegórica en la especificidad de su régimen sígnico, en las regiones del mundo social que demandan este régimen y en las pretensiones de estas demandas. Entonces, la composición alegórica se presenta como un régimen sígnico obligado ante todo a la traducción, que es urgida en las regiones del mundo social que saben que las representaciones no pueden ser desmanteladas en su totalidad de las cosas que ellas representan so pena de caer en abstracciones inasibles y que lo alegórico es indispensable para sostener el carácter colectivo de aquello que es representado pero negando a la colectividad misma que permite la representación. Se puede señalar, entonces, que en la composición alegórica pareciera residir todavía algo de la trama social denegada que está en el principio de la fuerza sagrada, sin dejar de mostrar, pese a ello, tanto el discernimiento de la fuerza como la fuerza discernida, cada vez más abstraída, primitiva en simbolismo. Por todo esto, la composición alegórica es objeto privilegiado de las artes que deben representar unas prácticas que aunque evidentes por elementales, que irredimibles de la materialidad y de la naturaleza, parecieran por lo mismo recubiertas con propiedades materiales y naturales y, por tanto, sometidas a los principios eficientes que el mundo social entiende están en el origen del comportamiento de lo material y lo natural, principios estos que no son evidentes, que tampoco están a libre disposición, que oscurecen lo inmediato, más aún, que son esotéricos: esto lleva a que la composición alegórica cabalgue entre lo evidente y lo oculto, entre lo familiar y lo extraño, lo que inviste a los objetos o a las prácticas que representa con una aura mística a la que solo se puede acceder por una suerte de disposición vocacional, por una actitud ascética, por un carisma. He allí las composiciones alegóricas que representan a la práctica de sanar o de ajusticiar, que amparan a la medicina o a la justicia, que obligan al médico o al juez.

La composición alegórica fue erigida en el recurso privilegiado para representar al Estado como una forma sublimada del mundo social, si se quiere, para representarlo como una forma perfecta de sociedad que la sociedad desconoce que se da a sí misma para que la gobierne en sus imperfecciones, que tiene en su base una materialidad y una naturaleza, incluso que tiene correspondencia con una especie sensible, un objeto animado o inanimado que guarece el principio totémico, ese que puede objetivar las propias fuentes de la perfección. En síntesis, el Estado como una forma "perfectificada" de lo social, que no es nada distinto a una versión petrificada del mundo social perfecto, que procediendo de lo colectivo está por encima de toda colectividad (la fuerza simbólica de esta composición depende de que la imagen de la sociedad sublimada nunca se manifieste como una imposición de determinadas fuerzas sociales que pueden por este medio establecer de modo arbitrario lo perfecto, incluso consignándolo en piedra como le sucediera a Moisés en el monte, convirtiéndolo en principio de poder y en modo de ejercicio del gobierno). De cualquier manera, esta composición alegórica del Estado, sin duda de ribetes religiosos, debe remontarse en la tradición occidental a la imagen del pastor con su rebaño: tanto del pastor con su poder pastoral, ese del que Foucault nos dijera "que se define en su totalidad por la benevolencia; [que] no tiene otra razón de ser que hacer el bien..." (Foucault, 2006: 155); también el pastor con su disposición a la renuncia, ese del que Girard nos dijera que frente al caos entrega la vida por sus ovejas, una víctima propiciatoria del sacrificio ritual que está en los principios de la violencia sagrada, que "es la matriz de todas las significaciones míticas y rituales" (Girard, 2005: 121). Sin duda habría que seguir esta composición alegórica, de ribetes religiosos, en la imagen del rey, con sus dos cuerpos imbricados, el sagrado y el profano, que tomados casi que strictu sensu de la teología medieval, proyectaron al Estado moderno desde la idea del corpus mysticum eclesiástico (Kantorowicz, 1985).

El Estado moderno, que surgió en el siglo XVIII con la Ilustración, no quedó al margen de esta saga, aunque las imágenes primordiales se estacionaron menos en el pastor original venido del Oriente o en el cuerpo místico de Cristo y discurrieron más por los rasgos excedidos en bondades de la antigüedad greco-latina: un mundo mediterráneo al que se le dibujó con unos modelos ejemplares en lo político, pues allí surgieron la primera democracia y la primera república; en lo social, pues allí tomaron forma unos valores ideales como la razón y la libertad; en lo cultural, pues allí irrumpieron unas expresiones estéticas, filosóficas y científicas que exaltaron al hombre en su individualidad sin detrimento de su generosidad colectiva, que no escindieron la glorificación de lo sagrado del disfrute plácido de lo secular. En síntesis, la antigüedad greco-latina fue revestida como un ancestro portentoso de las convicciones ilustradas, propicia para constituirse en fuente de las causas burguesas contra el Ancién régime. No obstante, bien se puede aventurar que detrás de la exaltación de estos modelos ejemplares estaba la creencia de que la virtud superior de la antigüedad greco-latina fue que pudo transferir los principios sagrados que antaño fueran 
exclusivos del dominio de la religión a otras actividades humanas, entre ellas, a la política, y que esta transferencia fue posible ante todo por la educación y por el arte, esto es, por la cultura en su acepción más general, que bien puede permutar o transfigurar disposiciones religiosas en disposiciones seculares sin abortar para nada, sin disminuir en un ápice, lo sagrado (cfr. Bourdieu y Darbel, 2003: 176). Valga decir que para la causa de entonces esto no era una cuestión cualquiera: en medio estaba la capacidad de hacerse en la práctica a aquello que por mucho tiempo aspiró la teoría, que no era otra cosa que la divina atributio que estaba en la base del poder monárquico, esa que hacía al rey la encarnación de lo perfecto gobernando un mundo de imperfecciones, esa que insuflaba el espíritu burocrático del Estado, en últimas, esa que era el principio primero de todas las prácticas consagradas y consagratorias del mundo social.

Ahora, si existe un arte que puede hacer manifiesta la capacidad de las prácticas culturales de permutar, transferir o transfigurar las disposiciones de lo sagrado en lo profano, de lo religioso en lo político, este es sin duda la arquitectura. Con el Ancien régime prosperó la arquitectura barroca, una propuesta y un estilo grandilocuente soportado en un régimen colonial de extracción de riquezas de ultramar, excedido en espacios y desmesurado en formas, que persiguió ante todo la exaltación de la monarquía con su nobleza y la abyección cuando no la abierta miserabilización de los súbditos. En oposición surgió la denominada arquitectura neoclásica, una propuesta y un estilo reclinado en la antigüedad greco-latina que estuvo en las entrañas de los tiempos ilustrados: una arquitectura racional en formas y contenidos, preocupada por la función de los espacios, pensada al tamaño de los hombres y las masas y entendida para ser contemplada ante todo por ciudadanos. Esta arquitectura se hizo a las estructuras monumentales de la antigüedad clásica, entre ellas a los templos, para convertirlas en fuente de lo que debían ser las estructuras monumentales modernas, para erigir los edificios del gobierno, para materializar de manera simultánea a los nuevos Estados burgueses y a sus ciudadanos. Bien se puede afirmar que en procura de este cometido, la arquitectura neoclásica fue prolija en composiciones alegóricas, necesarias para materializar tanto como para abstraer, para conectar la imagen con la fuerza, para cernir la fuerza de la imagen (cfr. Sennett, 1994; Gravagnuolo, 1998).

Sin embargo, el ejercicio orientado a permutar, transferir o transfigurar lo sagrado en lo profano, en capacidad de conducir la disposición trascendente a disposición inmanente para la vida compartida, solo sería progresivo, esto es, solo podía generalizarse para la sociedad como un todo, en la medida que la educación, el arte y la cultura fueran adquiriendo una situación tal de autonomía que el habitus incorporado por estos medios a los ciudadanos, sin conducir a ninguna creencia religiosa, permitiera no obstante creer de manera religiosa en el mundo social. Entonces, la autonomía sería principio fundamental para que los campos de la producción y de la reproducción simbólica pudieran revestir a la cultura como un producto sujeto a lógicas específicas que, en presunción ajeno a cualquier determinación social, económica y política, desconociendo o no reconociendo al tejido institucional que lo agenciaba, podía por ello presentarse como un derivado de la naturaleza cuando no como naturaleza en sí misma, indispensable por ello para naturalizar a gran escala la vida con el otro, la vida compartida. Sin duda esto es arte, tanto en lo que tiene de forma de magia como de magia de la forma, que permite que entre el yo y el otro, entre propios y extraños, entre nosotros, se materialice una fraternidad, esa misma que participa en las bases profundas de la ciudadanía. Si se quiere, el yo, el otro y el nosotros configuran una trama con la capacidad de producir una fuerza que, en apariencia concedida sin conciencia, es restituida en lo que esta fuerza tiene de sagrada por medio de la educación y del arte, por la cultura en su acepción más general. Esta es la economía profunda de la ciudadanía como identidad sagrada y del arte que participa en ella concediéndole su belleza. "No conozco nada sublime que no sea alguna modificación del poder", decía Edmund Burke (Citado por Taussig, 1995: 144-145).

Nadie tiene porque creer en lo que digo, mucho menos sentirlo, sobre todo acá en este país donde estamos tan acostumbrados a las formas más flacas de la ciudadanía, que no pareciera asunto sagrado sino reliquia en sus huesos, en lo habitual objeto de meros análisis racionalistas que emplazan cuanto puede decirse al respecto en el uso de los derechos, en la participación política y en la infaltable formación ciudadana. Por esto la ciudadanía que se auspicia para el país se reduce al curso y la cartilla, a la campaña y la propuesta, a la promesa y la dádiva, al elegido y sus electores, al borrador y la reforma, al proyecto en estudio y al proyecto aprobado, a la reglamentación y la sanción, que no tienen modo, que no hay forma, que no tienen por qué responder a ningún interés ciudadano, cuando ellos están al margen de lo que la vida compartida tiene de sagrado, que no es otra cosa que la soberana presencia del otro. 
Sí, eso, la soberana presencia del otro, algo que no dice nada en un país donde el otro vale una mierda: ciudadanía hecha de boñiga. Esta misma ciudadanía es la que queda perpleja ante la potestad generalizada que le ha sido concedida a tantos para asesinar, violar, secuestrar, corromper, robar, excluir, en últimas, para miserabilizar al otro y hacerle su vida una tragedia, incluso alegando tantas villanías en nombre de buenas causas o de presuntas causas superiores. Este es el país que pretende dizque reivindicar la memoria.

Por lo anterior, bien puede decirse que la negación de la ciudadanía prospera sobre un expolio original, que no es otro que el que se perpetra sobre la sociedad en el momento en que le es negado lo que le corresponde de esa fuerza sagrada que, producida entre todos de modo colectivo, debe ser restituida, bastante sublimada, casi que de modo oscuro, incluso individualizada, por medio de la educación y del arte, por la cultura en su acepción más general. Los derechos, la participación y la formación de los ciudadanos, ajenos a sus bases sagradas, ausentes de lo que ellos mismos tienen por arte consagratorio, terminan siendo un asunto de buena prédica política y de aspiraciones indispensables, que lo son, pero también terminan convertidos en objetos de fácil hurto por las formas más cavernarias, incluidas aquellas que en el colmo de los abusos agotan lo sagrado al entronizar la profesión religiosa: asunto casi catastrófico para las necesarias diversidades del mundo social, tanto más cuando tal profesión todavía exuda a la religión en sus modos más criminales y criminosos, como cuando avala el señalamiento, la estigmatización, la lapidación o el asesinato en un madero, es decir, esos modos que fueron característicos en los tiempos primarios de la religión, cuando ella requirió la eliminación de alguien, sacrificial es cierto, pero igual eliminación. La religión del chivo expiatorio.

Con el tiempo, esto es, con la edad, entendí que la magnitud de los edificios era solo cuestión de tiempo, esto es, de la edad. Los edificios que en mi niñez parecían inmensas catedrales imposibles de ocupación completa, fueron haciéndose cada vez más proporcionados en la medida que yo mismo crecía, tanto así que en determinado momento perdieron cualquier espíritu catedralicio para quedar reducidos solo a eso, a meros edificios destinados a cualquier cosa. Hay algo de la experiencia estética que solo se tiene en la infancia, que es imposible de conquistar más allá de este tiempo, que es intransferible así se interpongan todas las formaciones posibles, por portentosas que ellas sean: esta experiencia no es otra que esas maneras de disponer del mundo a medida que crecemos. Sí, la infancia pone a disposición el mundo de modos singulares para cada cual dependiendo, claro está, del mundo que está disponible para cada uno. Ahora, no se trata solo de la disposición de los objetos inmediatos, de las distancias entre ellos, del espacio que ocupan y de la manera en que lo hacen; también se trata de la manera como las formas se dibujan y son dibujadas, de los colores y los tonos, de los contrastes y las inclinaciones de la luz y la oscuridad, de la profundidad del horizonte. Es una disposición que no solo involucra lo visual, sino también lo táctil: los modos de tocar, de palpar, de sentir, de distinguir entre lo felpudo y lo áspero, de crisparse con lo roído y de estremecerse con lo lacerado, como las rodillas de Paulita después de que las restregara en el pavimento. Qué problema, pobre Paulita, pobre yo que no tuve la culpa, la culpa la tuvo el perro, aunque el perro era mío me dijo la mamá. Es una disposición que no solo involucra lo táctil, sino también lo auditivo: los modos de oír, de allegar los sonidos, de unirlos, de vincularlos, que nos permite escuchar la lluvia con tristeza, ora con alegría. Es una disposición que no solo involucra lo visual, sino también lo olfativo: los modos de oler o los olores percibidos, los que salen de la madera cuando la casa entró en una ruina incontenible, los que expele el saco de lana verde, que luego sería azul, después de pasarle los dientes. Es una disposición que no solo involucra lo visual, sino también el gusto: los modos de saborear, los sabores mismos, el sabor a ahuyama que aparece cuando la gente come sola, el de los cubios que aparece cuando la gente come angustiada. Sí, también la sospechosa tranquilidad del sabor de las habichuelas. Luego llegará la vida adulta, el mundo entonces tendrá por fin unas proporciones definitivas y estas experiencias primitivas quizá colapsen ante otras nuevas, más racionales o más intelectivas, apareciendo solo de cuando en cuando en los tránsitos de la memoria, esos que toman formas de nostalgias y melancolías: esa tarde luego de mucho fregarlo el perro corrió despavorido llevándose consigo a Paulita que restregó las rodillas contra el pavimento. Paulita solo lloró cuando se me ocurrió echarle agua oxigenada. El perro ladró, me denunció, me acusó y fui condenado por la mamá de Paulita. Motoso delator.

Entonces aparece la estación principal de los Ferrocarriles Nacionales, no aquella del pueblo, tan venida a menos, tan arruinada, sino aquella de la ciudad, la de la Sabana, coronada con ese pájaro inmenso de alas abiertas como dispuesto a llevarse al edificio a algún nido, suficiente para arredrar a cualquier niño que no más entrando podía sentir que allí, en medio de 

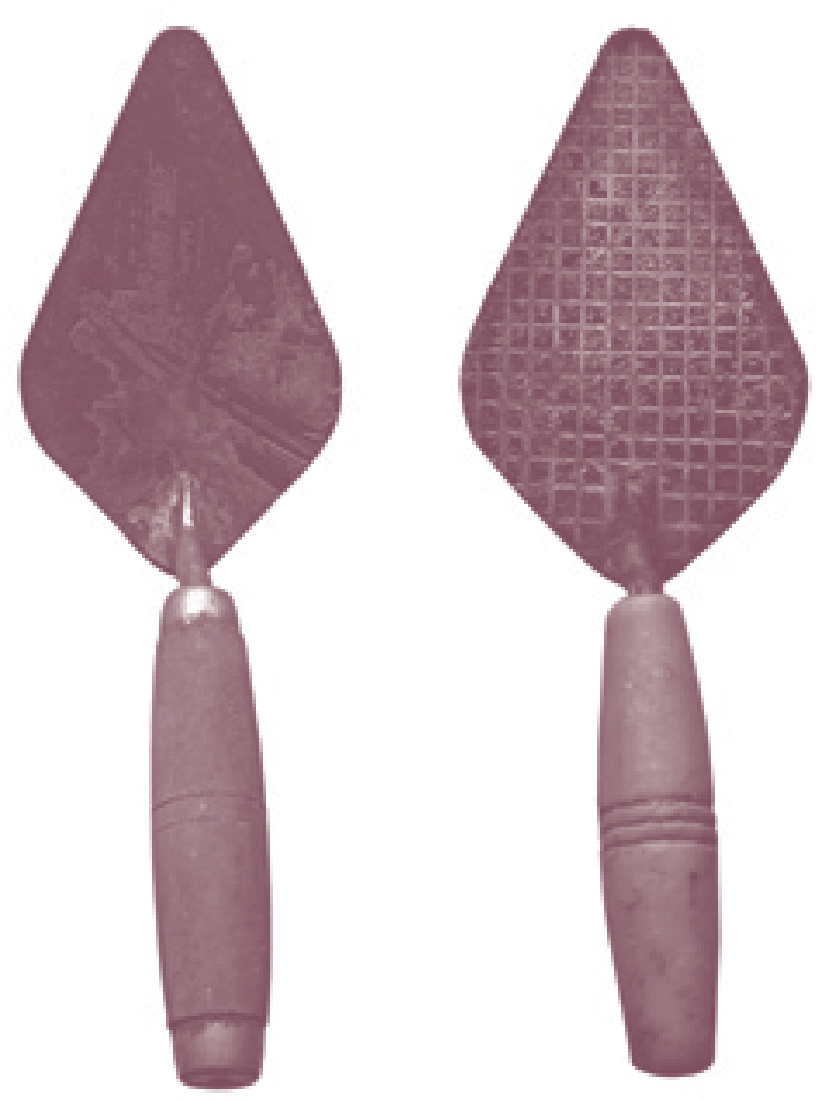

^ Palustres, José Julián Agudelo, 2010

esa profusión de columnas coronadas en laureles, bien pudiera tener cabida media humanidad, cuando no toda. Las estaciones de tren, en otras partes más que acá donde ha predominado el pensamiento troglodita y la mano raposa, fueron objetos privilegiados de una arquitectura decidida a alegorizar al Estado, a hacerlo manifiesto no solo en cuanto dueño de unas consecuciones técnicas en capacidad de acercar territorios y poblaciones, sino también, en cuanto a presencia apenas representable por interpuesta imagen, en nuestro caso, por esa del pájaro negro, de las columnas, de los balcones, de las tres entradas, de los ventanales, una disposición con tonos tan solemnes, a veces tan esotéricos en sus significados, que parecía bien concebida para albergar al amparo de alguna entidad sobrenatural a esas máquinas dormidas que, arreciadas por el fuego, tomaban la forma de alguna feroz especie antediluviana. Un espacio inmenso en magnitud y en estilo o cuando menos con la inmensidad que cabía en los ojos de un niño de apenas ocho años, cada vez más acostumbrado a ese salón que fuera antes una bodega, donde la generosidad del espacio era conculcada por la tacañería de las claraboyas, lo que nos obligaba a apelmazarnos, a juntarnos al extremo unos y otros, tanto que alcanzábamos a percibir en toda su
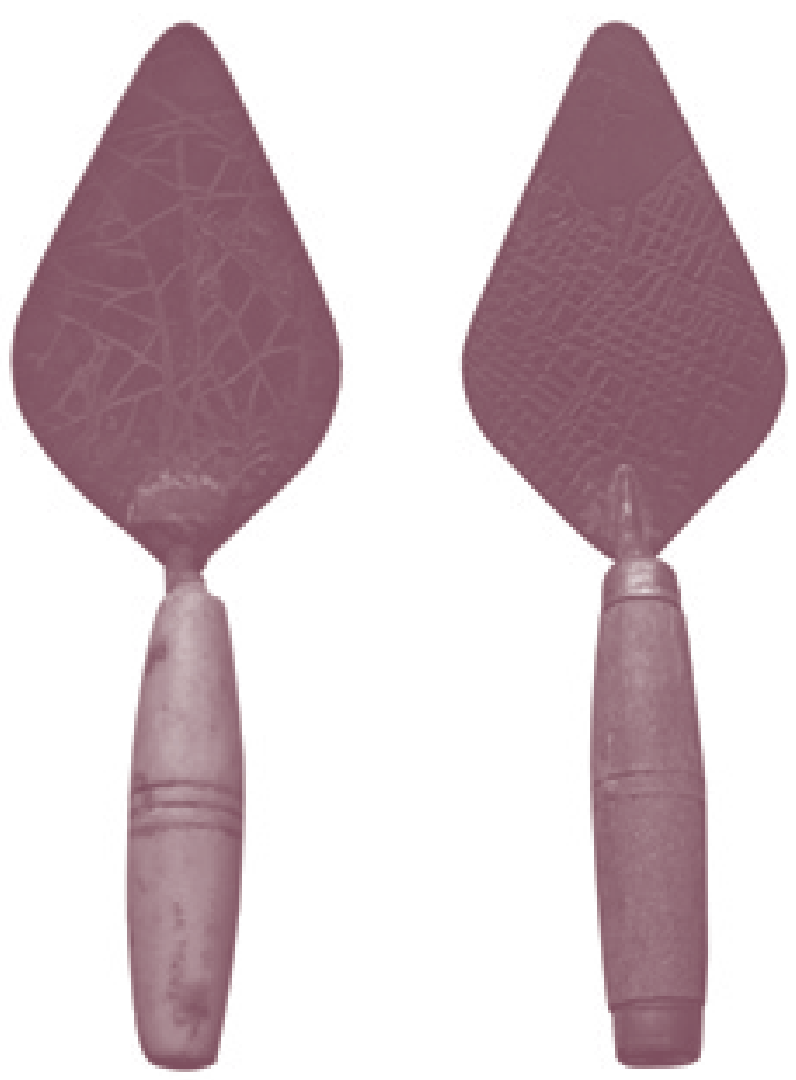

intensidad los olores fétidos de Raúl, cada vez peores, cada vez más expansivos, como si adentro de alguno de sus oídos, quizá de los dos, hubieran muerto todas las palabras oídas y por oír y en su putrefacción estas exhalaran cosas nauseabundas, todo lo cual parecía incidir en la incapacidad del muchacho para entender lo que se le decía, para aprender del maestro en clase y para revertir las elegías difamatorias que advertían que su caso era uno de flagrante estupidez. Sin embargo, su madre parecía entenderlo, abrazándolo como lo abrazaba entre ese bullicio de gentes que salían como desmadradas al fragor del medio día. Luego le pasaba el brazo por encima del cuello, se iba con él, que sonreía, que era feliz entonces, seguro decidida a escucharlo en medio de una sopa, aunque ella supiera, como luego se supo, que en sus oídos morían las palabras tan pronto llegaban.

\section{Universitas}

Poco se habla ahora de la trama social y de la fuerza sagrada en asuntos de educación, sometidos como están estos asuntos a tantos discursos, desde los que reducen lo educativo a una mera transacción en lo 
cognitivo, lo social y lo económico, "claro a todas luces" dirá el gerente que vende servicios educativos como vender fruslerías en cualquier abacería inscrita en la cámara de comercio, hasta los que revisten lo educativo como una práctica oscura que nos hace peores en algo o cómplices de todo, aunque no siempre digan en qué o de qué modo, postura lúcida en cuanto se percata de lo sagrado, aunque solo pueda entenderlo en el sentido de lo sagrado impuro, del hecho maldito. Obvio que si el primer discurso es el del mercachifle pedagógico que pulula sin contención, el segundo tiende a ser la inspiración para el profesor profeta, ese extraño ejemplar que debe a su condición profética la capacidad de anunciar desastres y a su condición docente la de anunciar desastres que ya sucedieron: estos profetas que anuncian lo que ya sucedió tienden a ser los descreídos de todo, los que acusan a la educación por canalla, los que entierran a instituciones como la escuela, obvio que a la universidad, a los que no les sirve nada de la tradición, ni siquiera la capacidad de crítica que la tradición engendró contra sí misma, que usan trucos teóricos que siempre son trucos retóricos, siendo en muchos casos versiones recicladas del profesor alternativo de colegio, por lo habitual del humanista díscolo que sobrevive aún gracias a la herencia perdurable que dejara John Keating y su carpe diem.

Sin embargo, al restituir la trama social, la fuerza sagrada y la retribución por gracia de la educación, del arte y de la cultura, se abre un lugar para no reducir el asunto educativo al racionalismo utilitarista en el que pelecha desde el liberal clásico hasta el neoliberal conservador, ni tampoco a ese oscurantismo ideologizante por donde discurren desde los marxismos más anquilosados hasta distintos posestructuralismos. Para esto bien vale atender a uno de los colegas más próximos de Walburg, a Erwin Panofsky. En uno de sus trabajos más célebres, por lo demás una pequeña obra maestra de la historia del arte y de la cultura, Panofsky planteó una relación profunda, estructural, entre la arquitectura gótica y el pensamiento escolástico. De varios elementos se valió Panofsky para introducir esta relación: la correspondencia cronológica entre el ascenso, el apogeo y el declive de la arquitectura gótica y lo que fuera el desarrollo del pensamiento escolástico, todo esto entre el 1080 y el 1320; la correspondencia espacial que llevó a que en París y sus alrededores, en cien millas a la redonda, se emplazaran tanto los ejemplares mejor logrados de la arquitectura gótica como los principales centros de divulgación de la escolástica; la correspondencia social que condujo a que la arquitectura gótica se afianzara allí donde también ascendieron esas nacientes burguesías de finales de la edad media, decididas o convencidas en el escolasticismo (Panofsky, 2007).

Pero la relación, como señalara Panofsky, implicó algo más que un paralelismo o una casualidad: fue una relación profunda, "una concurrencia tan ineludible que los historiadores de la filosofía medieval, sin estar influenciados por consideraciones ulteriores, han periodizado su material exactamente del mismo modo que los historiadores del arte el suyo" (Panofsky, 2007: 27). Esta relación profunda tiene en medio transformaciones sustanciales en la educación: “La enseñanza pasó de las escuelas monásticas a instituciones que eran más urbanas que rurales, más cosmopolitas que regionales y, por así decirlo, solo a medias eclesiásticas: las escuelas catedralicias, las universidades y los studia de las nuevas órdenes mendicantes (casi todos ellos producto del siglo XIII), cuyos miembros jugaron un papel cada vez más importante dentro de las universidades" (Panofsky, 2007: 36). Para decirlo en otros términos, la relación profunda entre el gótico y la escolástica tuvo en medio un desplazamiento progresivo de la educación, que pasó de ser un asunto suscrito de manera única a la iglesia y que avanzaba en la supremacía exclusiva de la fe, a un asunto que cayó dentro de las preocupaciones de otros estamentos, que avanzó hacia unas discusiones más sensibles sobre los vínculos entre fe y razón, y que tuvo como uno de sus lugares privilegiados, quizá el que más, a la universidad.

Fueron la educación y el arte, en general la cultura de la edad media tardía, con el conjunto de sus prácticas, desde la disputatio hasta la summa, la que permitió que entre los principios arquitectónicos del gótico y los principios filosóficos de la escolástica se tendiera un puente, "una genuina conexión", dirá Panofsky, por medio de un "hábito mental", "limitando este ya gastado cliché a su significado escolástico de 'principio que regula el acto', principium importans ordinem ad actum" (Panofsky, 2007: 35, resaltado en el original). Este concepto de "hábito mental", que será determinante para que Bourdieu elabore la idea de habitus que planteara por primera vez en sus etnografías argelinas, le permitió a Panofsky esclarecer cómo la visión escolástica del mundo pudo transitar a la arquitectura gótica y, de manera simultánea, cómo la arquitectura gótica fue, en mucho, la realización de la filosofía escolástica. Más allá, pero ahora con Francis Yates, se puede afirmar que la visión arquitectónica de la escolástica, con su modo de emplazar espacios y de organizarlos, resultó determinante para el pensamiento medieval, por ejemplo, para el arte de la memoria, que "fue un 
creador de imágenes que debieron seguramente de emerger en creativas obras de arte y literatura" (Yates, 2005: 113).

Una disquisición preciosa la de Panofsky, que permite adelantar dos consideraciones: primero, que la educación está rodeada de un repertorio material inscrito en la historia y en la sociedad; segundo, que este repertorio material, modelado por el arte, desde las entrañas del artista, participa de manera fundamental en los modos como la educación puede no solo organizar y administrar unos conocimientos e incorporar unas disposiciones cognitivas y cognoscitivas, sino, más allá, transferirlas bajo la forma de formaciones duraderas, de habitus, a otros ámbitos, a otras prácticas, entre ellas, a las vinculadas con el discurrir público, con el ejercicio político, con la ciudadanía. Con estas dos consideraciones se puede afirmar que el repertorio material de la educación dominado por las artes, entre ellas por la arquitectura, resulta fundamental para conducir a un lugar específico, para emplazar en un entorno concreto, la retribución de lo sagrado en lo secular, sin lo cual la educación pierde su carácter colectivo y trascendente, siendo reducida a un intercambio indistinto de pura información, transmisible de cualquier modo, vendible como mercancía. De hecho, la relevancia de los repertorios materiales en la educación se puso de manifiesto también en la universidad moderna, en aquella surgida con la Ilustración, concernida con un nuevo orden, que debía estar patente en la organización de los terrenos universitarios, en la composición de los edificios, en el diseño de los campus. El llamado de Humboldt a vincular la formación en ciencia con la vocación en artes, que haría parte sustancial del ethos universitario moderno, debía hacerse visible en la edificación universitaria, incluida en ella la presencia de la composición alegórica que materializaría la representación de los saberes, de las disciplinas, de las ciencias. Esto llegó incluso hasta nosotros.

En efecto, desde finales de los años veinte se dispuso como asunto de urgencia una reforma a la Universidad Nacional que la sacara de manera definitiva de su carácter de avejentada institución decimonónica ausente de los desafíos de la ciencia, del arte y de la cultura que se sabía entonces debían transformar al mundo. La Universidad era una institución sin profesores de carrera, que dependía de ilustres profesionales por hora mal pagados, muchas veces incumplidos, que apenas si ejercían por el honor; tenía la Universidad estudiantes de todas las procedencias, avalados por un título de bachiller que los certificaba en las más extrañas habilidades, algunas de tonos medievales, que además gustaban de gastar parte de su tiempo en rondar los cafés del centro y los palcos del Congreso haciendo barras y cazando debates; la Universidad dependía de una estructura de facultades sin conexión, cada una sometida a un rector, cada rector sometido al ministro de Educación y este a su vez al presidente de la República; su relación con la sociedad era solo a nivel de empleos, sin mayor impacto más allá de la administración pública y la política; su planta física, con alguna excepción, era pobre, venida a menos, conformada en lo habitual por herencias de instituciones de otros siglos, casas viejas disgregadas por muchas calles de la ciudad. La reforma a la Universidad debía ser estructural, sin medias tintas, para lo cual los asesores contratados por los gobiernos liberales de los años treinta propusieron: profesionalización de la carrera docente, cualificación del ingreso de estudiantes por medio de la adopción de un examen de admisión soportado en pruebas psicotécnicas, la concesión de la autonomía universitaria plena, la creación de una unidad de divulgación cultural fuerte que robusteciera los vínculos entre una universidad autónoma con la sociedad y, con esto, para todo esto, la construcción de un campus universitario al mejor estilo de las grandes universidades del mundo, fuera de la ciudad, con edificios bien dotados, con amplios espacios verdes, que concitara la residencia y el encuentro tanto como la reflexión, la contemplación y el esparcimiento. El rector tendría su casa personal y los docentes y estudiantes sus residencias en inmediaciones del campus. Con esta reforma, diría Germán Arciniegas, el gobierno liberal apuntó a la constitución de una auténtica república universitaria (Serna Dimas, 2006).

Todo fue acometido, aunque no todo se concluyó. Dentro de las medidas adoptadas estuvo la destinación de parte del inmenso predio que fuera de la hacienda El Salitre para la construcción de un gran campus universitario. Para esta iniciativa el Ministerio de Obras Públicas contrató al arquitecto alemán Leopoldo Rother, quien sería responsable de materializar la propuesta pedagógica del también alemán Fritz Karsen. El proyecto de concepción, diseño y construcción de la Ciudad Universitaria apuntó entonces a englobar todos los conocimientos en seis grandes áreas, "ciencias sociales y políticas, ciencias naturales, química, ingeniería, artes aplicadas y las instituciones generales", cada una con sus respectivos edificios alrededor de una gran plaza principal o en sus áreas concéntricas, todo dentro de un diseño espacial que reproducía la imagen de un búho, la especie animal que en la antigüedad fuera la 
representación de la sabiduría: así, el campus entero se pensó como una inmensa alegoría, que no era cosa cualquiera, sino que encarnaba tanto lo que se debía estudiar como el modo que debía estudiarse. Para alzar el trazado, para concretarlo en edificaciones, nada mejor que el cubismo de la Bauhaus, con sus volúmenes perfectos y limpios, funcionales tanto para la actitud racional como para la contemplativa, disposiciones propias de las gentes universitarias. Las edificaciones fueron contratadas con el propio Rother, así como con arquitectos como Violi, Wills, Acevedo, Lange y Blumentahl, entre otros, todos ellos formados o influidos por el modernismo arquitectónico (Hofer, 2003: 97). Como quiera que fuere, la Ciudad Universitaria o Ciudad Blanca resultó determinante para el destino futuro no solo de la Universidad sino también del país: el campus fue definitivo para que la Universidad se hiciera en verdad universal en sus pretensiones de conocimiento y nacional en sus pretensiones sociales.

Veinte años después de acometer el diseño y de participar en la construcción de la Ciudad Universitaria, Leopoldo Rother aceptó del naciente Distrito Especial de Bogotá la solicitud para diseñar también el plano general para la construcción de la sede de la Universidad Popular del Distrito Francisco José de Caldas, que así se llamaba entonces. El encargo al parecer se realizó, si se tiene en cuenta la Resolución 1980 del 30 de diciembre de 1957 por medio de la cual el alcalde autorizó el pago de los honorarios acordados al arquitecto alemán, que fueron quinientos pesos (Anales del Concejo, XXIV, 247: 60-61). No obstante, del plano no se sabe nada, allí donde lo he preguntado nadie da razón, quizá está refundido en algún escaparate, llevando consigo una instantánea de lo que este arquitecto moderno pensaba debía ser una universidad para los hijos de las clases trabajadoras de la ciudad. Habría que pensar en promover la recuperación de este plano como un testimonio precioso de la historia de la Distrital: propongo a las directivas de la Universidad que para alguna de nuestras conmemoraciones se estipule un premio especial dirigido a quien busque y encuentre esta pieza.

La reforma a la Universidad Nacional en los años treinta, pese a lo lenta que fue su implementación y a la limitación de sus resultados en algunos frentes, en particular en la conformación de una tradición investigativa, no dejó por ello de ostentar el espíritu de lo que debe ser siempre, en toda circunstancia, una reforma universitaria: un auténtico proyecto cultural, esto es, una propuesta de plazos variables que soportada en los análisis más sesudos está orientada a incidir en todos y cada uno de los puntos de contacto que tienen la universidad y la sociedad, conmoviendo con ello los cimientos de una y de otra. Poco de esto se percibe hoy en día en nuestro sistema universitario, que pareciera cada vez más atolondrado ante el fárrago de demandas instrumentales que soporta, las cuales cumple de manera obcecada y abnegada, sin que en muchos casos sepa de modo exacto qué le aportan estas a su misión cultural, sustrato de su carácter político, que hay que decirlo, va mucho más allá de dictar y recibir clases. Porque en últimas a eso pareciera reducirse cada vez más nuestro sistema universitario, a impartir y a atender clases, en unos casos con todas las exclusividades y las exclusiones, en otros de manera masiva, dizque democrática, que es el modo de galvanizar la forma más vil de entregar el derecho a la educación, que es por medio de la caridad, asunto que los ánimos cristianos tienen por virtud más encomiable, pero que en materias educativas es el peor de los pecados: la educación por caridad, dispuesta en cualquier forma, ofrecida en las peores condiciones, miserabiliza y preserva el statu quo, tanto que puede terminar convirtiendo la privación material en pura privación cognitiva y cognoscitiva, grandísimo favor que le hacen tantas instituciones educativas a unas élites obtusas como las de este país, que por siempre han considerado a la gente en situación de pobreza estúpida por naturaleza y que de hecho así la tratan. Vale recordar que si hay algo peor que no tener educación es tenerla mala, pues mientras la ausencia de educación es una injusticia que siempre será condenable incluso por quien la padece, tenerla pero mala es una condena que se hace pasar por justa incluso para quien la padece.

Mi escuela tenía su candor: aunque estaba instalada en el centro del trajín de los trenes, algunas gentes hacían esfuerzos por preservarla de la ruina definitiva que pudiera llevarla a su cierre. Esto sería una catástrofe para las gentes de los barrios inmediatos, claro que sí. No es de ahora que los gobiernos saben que nada mejor para clausurar cualquier servicio público, entre ellos el educativo, que auspiciar o desentenderse de su progresivo deterioro físico, toda vez que esto contribuye a cuestionar más que a funcionarios ineptos a la función pública como un todo, a hacerse al favor de la opinión masiva para una eventual liquidación y, sobre todo, a inhabilitar o deshabilitar el servicio por agotamiento del servicio mismo. Véase nada más la Ciudad Universitaria, cada vez más depauperada por el recorte en los presupuestos, cada vez más desarreglada por la ausencia de criterios en materia de planeación física, 


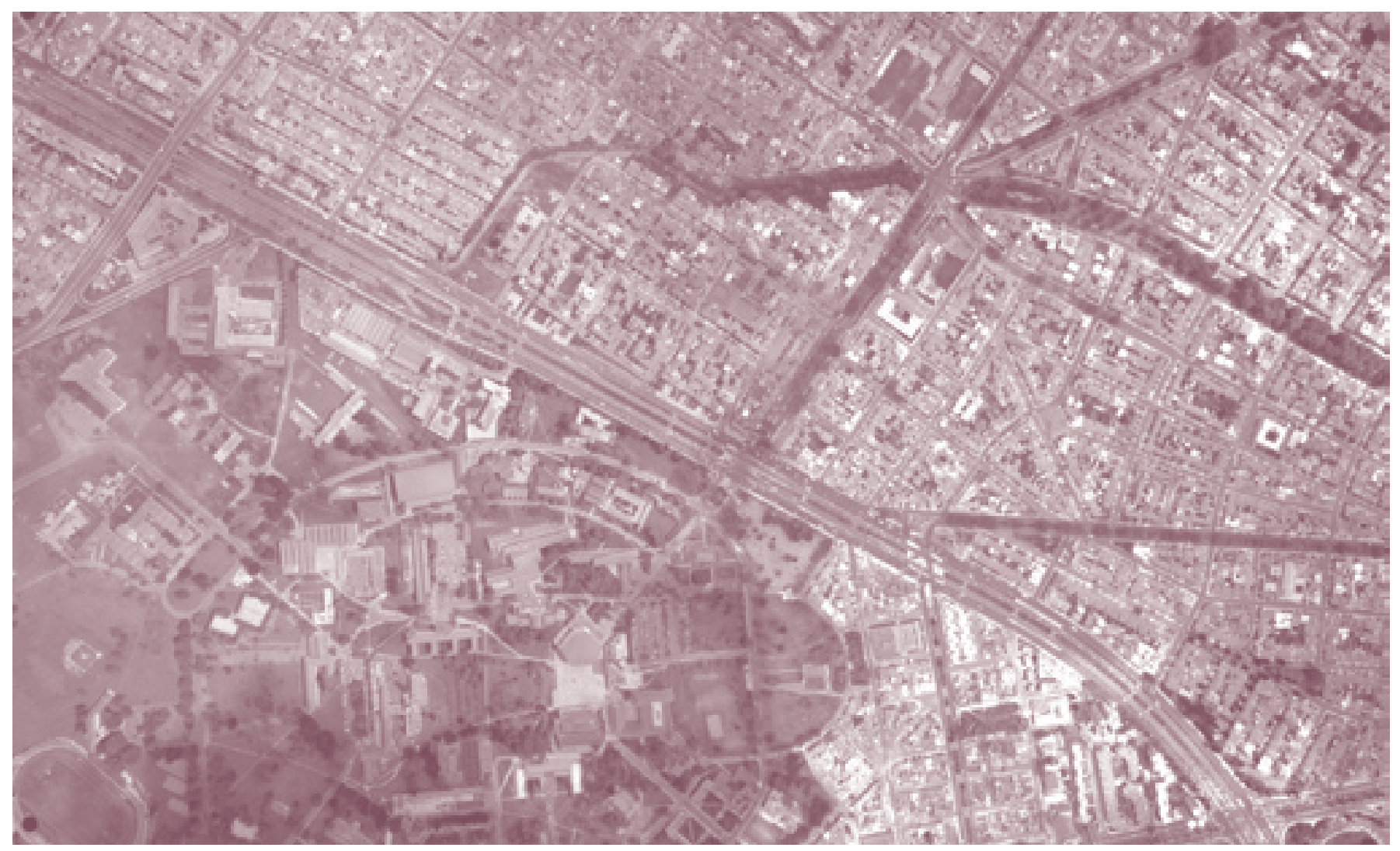

^ Aerofotografía de la Universidad Nacional en: IGAC, 1990

cada vez más arruinada por la falta de mantenimiento en sus edificios, tanto así que está sucediendo lo que sueñan tantos gobiernos autoritarios: la clausura literal de instalaciones hasta nueva orden. Y así están las otras universidades públicas, quizá en peores condiciones, con el agravante de que la cuestión del espacio físico, de su sostenibilidad para abrigar a la universidad como un proyecto cultural democrático, le parece a muchos una mera sensiblería pequeño-burguesa. Lo sorprendente es que esto lo dicen incluso gentes que estudiaron en otras universidades de aquí y del exterior, es decir, los afortunados que tuvieron privilegios que a nuestra universidad pública y a sus estudiantes, a los de acá, le son cada vez más negados, como tener buenos salones, pero también ambientes para analizar y debatir, para meditar y reflexionar, en últimas, todo aquello que supone más que dictar clases, todo aquello que permite que la escuela pueda democratizar con pleno derecho a la cultura, que es lo que garantiza a la cultura como derecho pleno. Contra el presunto gusto pequeño burgués se alían de manera paradójica quienes creen que la universidad solo debe ser masa y fuerza y quienes creen que la universidad solo debe producir mano de obra y barata. Puro neoconservadurismo.
A los problemas de la infraestructura física se suma también ahora la privatización de la función estética por parte de los propios actores de la vida universitaria, entre ellos los estudiantes, quienes no consideran bueno delegar la representación de sus causas en las manos del artista, cosa que fuera tan común en otras épocas cuando tales causas entrañaban profundas solidaridades, incluso fraternidades sentidas. Algo queda aún en los muros de nuestras universidades de ese viejo arte que fuera producto de la delegación que hicieran los estamentos en sus artistas, quienes procuraban concitar los espíritus, asociar las gentes, arrear las acciones colectivas, elevar a planos trascendentes las razones más inmediatas. Toda una vocación por la sensibilidad del otro, es decir, una vocación hacia lo público. Ahora, por el contrario, en medio de la caridad democrática, cada cual se reclama artista exclusivo de lo que cree, por pequeña que sea la creencia, incluso por pequeño que sea el talento, lo que ha suscitado una proliferación de marañacos contra la arquitectura universitaria, con mensajes que se anulan entre sí, que no pretenden decir nada a otros, donde todo se dice para sí mismo, lo que conduce a que la generación inmediata no tenga legado distinto al vacío de lo incomprensible, condenada a estudiar en las miserias que le deja el individualismo de nuestro tiempo. Es entonces 


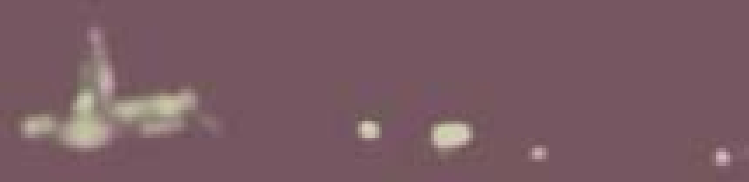




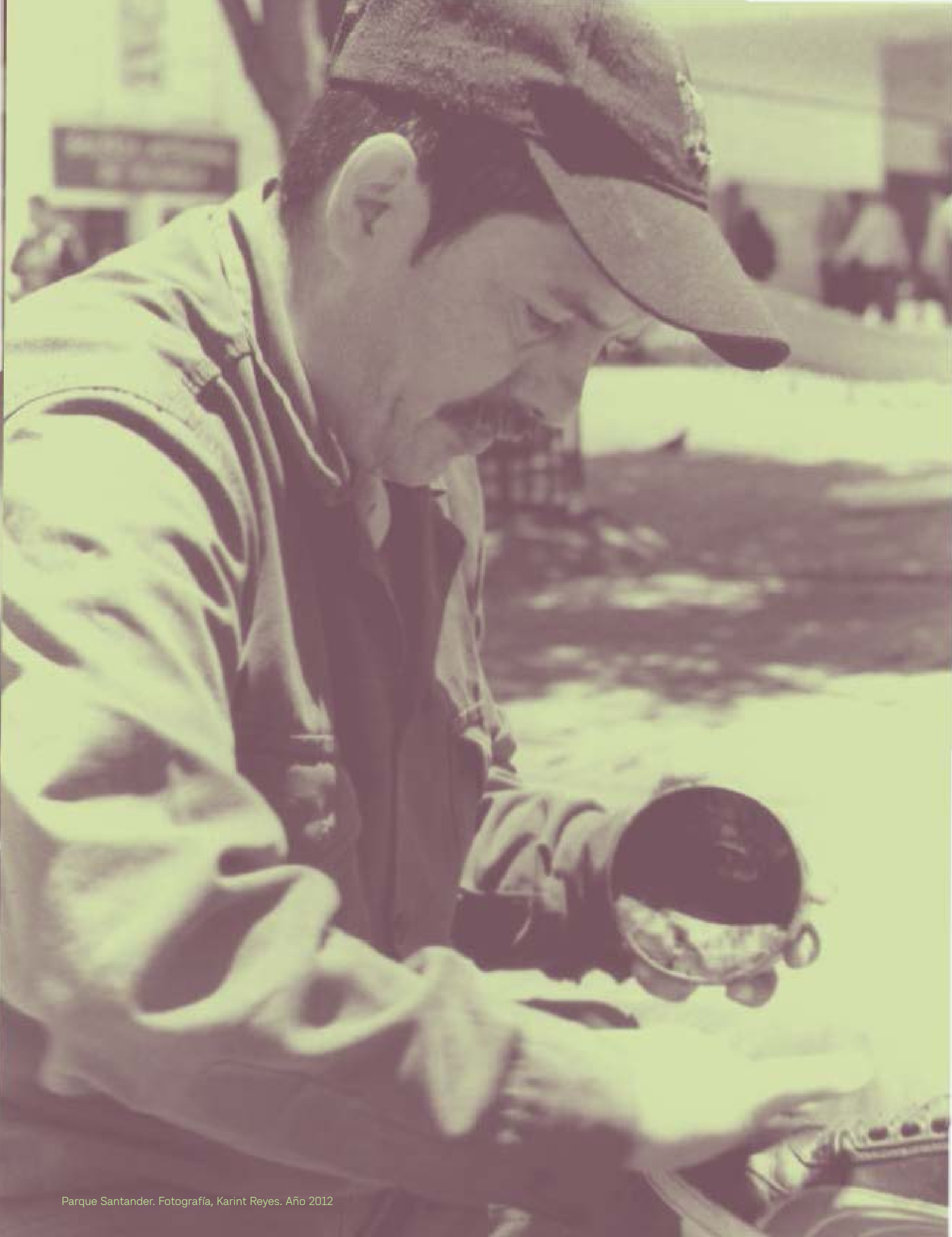


cuando el deterioro físico de la universidad se muestra como un síntoma de fenómenos más profundos, incluso más preocupantes: la erosión de las formas de asociación y organización de los distintos estamentos, la quiebra de la fraternidad universitaria, la disolución de la vida pública en los campus, el desmantelamiento de los espacios y las dinámicas culturales que garantizan la concurrencia del demos universitario, en unos casos espacios y dinámicas agotados por la deficiencia absoluta de materialidades, por la inexistencia de condiciones para hacer algo más que dictar clases; en otros casos espacios y dinámicas sustituidos de manera abrumadora por la política, tanto que se hace imposible hasta la política misma.

En los últimos días del mes de septiembre todavía reinaban sobre la escuela esas tesituras grises que dejaban los aguaceros, los que desmedidos se venían encima casi al final de la mañana, justo a la hora de la salida. Una mierda salir de la escuela en esos días, por entre una calle destapada hecha fango, de la que solo podía librarse el transeúnte cruzando la carrilera, esto si iba para los barrios, o pasando al andén del frente, esto si iba para el pasaje o para esas casas maltrechas que actuaban como pensiones miserables. Luego de la salida, cada muchacho, solo o en grupo, se hacía a su propia ruta: estaba la ruta del equilibrio, a lo largo de la carrilera, pasando frente a la grúa muerta hacía casi cinco años, luego por el tanque de aprovisionamiento con la manguera chilingueada, para bordear parte del taller hasta llegar al primer potrero, ese de donde salían cinco perros bravos y uno más bien manso; estaba la ruta larga, esa que iba por la calle vieja que en verano era polvo y en invierno un pichal, que luego doblaba en la esquina donde estaba la casita del suichero, para continuar hasta el final del barrio; estaba la ruta para el parque principal, pasando por el pasaje o la calle de los abogados, atravesando dizque la avenida, exponiéndose a un bus; estaba la ruta extraña, esa que parecía conducir a ningún lado, algo secreta, como por entre malezas y tapias gruesas, custodiada por las últimas ramas de papayuelos, cerezos y brevos, donde se veían muchos palomares con zuros, de esos que preparaban en caldos bien hervidos para recuperar a enfermos. Era una ruta extraña además porque más adelante se abría una inmensa compuerta, algo así como un gran cambio de vía, a donde iban a morir los trenes viejos. Entre las tapias perdidas de la ruta extraña, en alguna de ellas, vivía Raúl con su madre.

\section{El carácter primitivo de Vargas Llosa}

Amplio revuelo causó en diferentes ambientes el último libro de Mario Vargas Llosa (2012), dedicado a lo que él tilda de civilización del espectáculo. Aunque el libro tiene muchas voces a favor, creo que tiene tantas o más en contra, no solo desde una vieja intelectualidad de izquierdas que no pierde oportunidad para ajustar cuentas con el nobel peruano, sino también desde una intelectualidad más reciente, menos ubicua y más gaseosa, que encuentra en el conjunto de ensayos solo un reclamo anacrónico desde una concepción aristocrática y obsolescente de la cultura. A mí lo que más me llamó la atención en un principio fue que en un libro dedicado a mostrar la banalización de la cultura se acogieran tantos ejemplos procedentes de nuestro país, en particular en el ensayo central que le da título a la obra. Por ejemplo, cita Vargas Llosa a un amigo colombiano que le refiere "el neoindigenismo que practican, como nueva moda, las clases altas y medias bogotanas" (43); también a Carlos Granés Maya cuando refiere "una de las performances más abyectas que se recuerdan en Colombia, la del artista Fernando Pertuz, que en una galería de arte defecó ante el público y, luego, 'con total solemnidad', procedió a ingerir sus heces" (50); también a Tomás Eloy Martínez, quien en uno de sus últimos artículos, "se indignaba por el acoso a que sometieron los periodistas practicantes del amarillismo a Ingrid Betancourt y a Clara Rojas, al ser liberadas, luego de seis años en las selvas colombianas secuestradas por las FARC" (57). Esto sin tener en cuenta en este ensayo central, pero también en los otros, una cantidad de ejemplos sobre la banalización de la cultura que, aunque sin un lugar específico, también son evidentes en este país, tanto o más que en ningún otro.

En general, en la superficie, se puede estar de acuerdo con muchas de las afirmaciones que hace Vargas Llosa sobre el destino de la cultura como producto mediático contemporáneo, así ellas revuelquen los entresijos de tanto crítico posmoderno. Sin embargo, son controvertibles algunas de las premisas más fuertes de su crítica $y$, en consecuencia, el diagnóstico que se construye sobre ellas. Por ejemplo, Vargas Llosa remonta la disolución de la cultura como especificidad distintiva de las sociedades y de los individuos a un lugar inesperado, al quehacer de los antropólogos: "La más remota señal de este proceso de progresivo empastelamiento y confusión de lo que representa una cultura la dieron los antropólogos, inspirados, con la mejor buena fe del mundo, en una voluntad de respeto y comprensión 
de las sociedades primitivas que estudiaban. Ellos establecieron que la cultura era la suma de creencias, conocimientos, lenguajes, costumbres, atuendos, usos, sistemas de parentesco $y$, en resumen, todo aquello que un pueblo dice, hace, teme o adora". Luego dice: "Esta definición... quería... de entrada, abjurar del etnocentrismo prejuicioso y racista del que Occidente nunca se ha cansado de acusarse (sic). El propósito no podía ser más generoso, pero, ya sabemos, por el famoso dicho, que el infierno está empedrado de buenas intenciones" (2012: 66). Y no se detiene allí: “Una cosa es creer que todas las culturas merecen consideración ya que en todas hay aportes positivos a la civilización humana, y otra muy distinta, creer que todas ellas, por el mero hecho de existir, se equivalen" (66). Termina concluyendo: "La corrección política ha terminado por convencernos de que es arrogante, dogmático, colonialista y hasta racista hablar de culturas superiores e inferiores y hasta de culturas modernas y primitivas. Según esta arcangélica concepción, todas las culturas, a su modo y en su circunstancia, son iguales, expresiones equivalentes de la maravillosa diversidad humana" (67).

La definición de cultura que Vargas Llosa asume para la antropología es bastante próxima a la que fuera una de las más emblemáticas dentro de la disciplina, la que propusiera Edward Burnett Tylor por allá en 1871. No obstante, tal definición, pese a su uso recurrente, perdió ascendencia en la antropología y, diciéndolo con algo de abuso, ella entró más temprano que tarde a ese repertorio de caracterizaciones de lo cultural que por generales, cuando no por genéricas, fueron desmanteladas de potestades teóricas y metodológicas: la antropología, tanto más la que surgió en las primeras décadas del siglo XX, trabajó con definiciones de la cultura más complejas, con mayor poder heurístico; incluso hubo enfoques que prescindieron del término mismo de "cultura" en beneficio de otros, como los de estructura, pauta o sistema. Pero más allá se puede afirmar que en independencia de la definición adoptada, fuera la de Tylor o la de Radcliffe-Brown, resulta bastante discutible señalar que la presunta disolución de la cultura como especificidad de las sociedades y sobre todo de los individuos tuvo en su base una práctica profesional: suponer esto no es otra cosa que pretender hacerle el quite a los múltiples factores que llevan a que la cultura se convierta en mercancía, realidad que Vargas Llosa ejemplifica pero nunca señala de manera explícita, lo que le impide reconocer que detrás de la civilización del espectáculo está la mercantilización de la civilización, asunto de las entrañas de esa tradición intelectual de izquierdas que pasa por
Gramsci, Lukács, la escuela de Frankfurt, la escuela de Birmingham e inclusive por la propia antropología de Pierre Bourdieu. Sin saber si Vargas Llosa prescindió de esta tradición por sesgos ideológicos, que es harto posible, o por ignorancias académicas, que son poco probables, sí se puede señalar que en el nobel se pone de manifiesto la actitud de quienes teniendo una relación intelectual con la cultura suponen que la cultura depende solo de prácticas intelectivas.

Cualquier relación con la cultura de talante solo intelectivo tiende a poner al margen o a desconocer las diferencias que existen entre la cultura, la estética y el arte: la cultura supone todo cuanto es producido, la estética todo cuanto es producido sin que el producto cumpla una función inmediata de carácter utilitario y el arte todo cuanto es producido que por efecto de la sublimación no solo puede ser denegado de cualquier función mediata o inmediata de carácter utilitario sino que, más allá, pareciera no implicar producto ni función alguna, todo un acto de consagración de una segunda naturaleza como si fuera la primera, que solo se expresa en la obra de arte cuando ella es digna de tal nombre. La relación con la cultura de talante solo intelectivo, al desconocer estas diferencias, que son de grados, también de matices, lleva a considerar que la cultura es siempre y en toda circunstancia estética o artística, de tal suerte que aquello que está en la cultura se subsume de inmediato como arte y lo que no cabe en la cultura no tiene tampoco nada de artístico. Aún más: llega el punto en el cual esta relación con la cultura de talante solo intelectivo puede considerar que aquello que tiene solo cometidos inmediatos con la vida, como dar trámite a una costumbre cualquiera o atender alguna necesidad fundamental, no siendo asuntos artísticos ni estéticos, tampoco tienen ningún carácter cultural. Ahora, valga recordarlo, no es solo una cuestión de juicio o de gusto: toda declaratoria estética es, de igual modo, una declaración ética, constitutiva de auténticos estilos de vida (Bourdieu, 1999ạ: 283). De manera paradójica, la relación intelectual con la cultura que defiende Vargas Llosa, no lo deja a mucha distancia de la relación intelectual con la cultura que también está inscrita en las denominadas sociedades primitivas, donde las diferencias entre cultura, arte y estética tienden a ser sutiles, bastante atenuadas, tanto así que pareciera que la cultura subsume de inmediato al arte o de que nada hay en lo cultural que no sea de suyo artístico. Para decirlo en términos más sencillos, Vargas Llosa en materia de cultura y arte tiene un carácter primitivo, aunque alguien bien pudiera decir que aquí, una vez más, el nobel tiene la razón: la antropología, con 


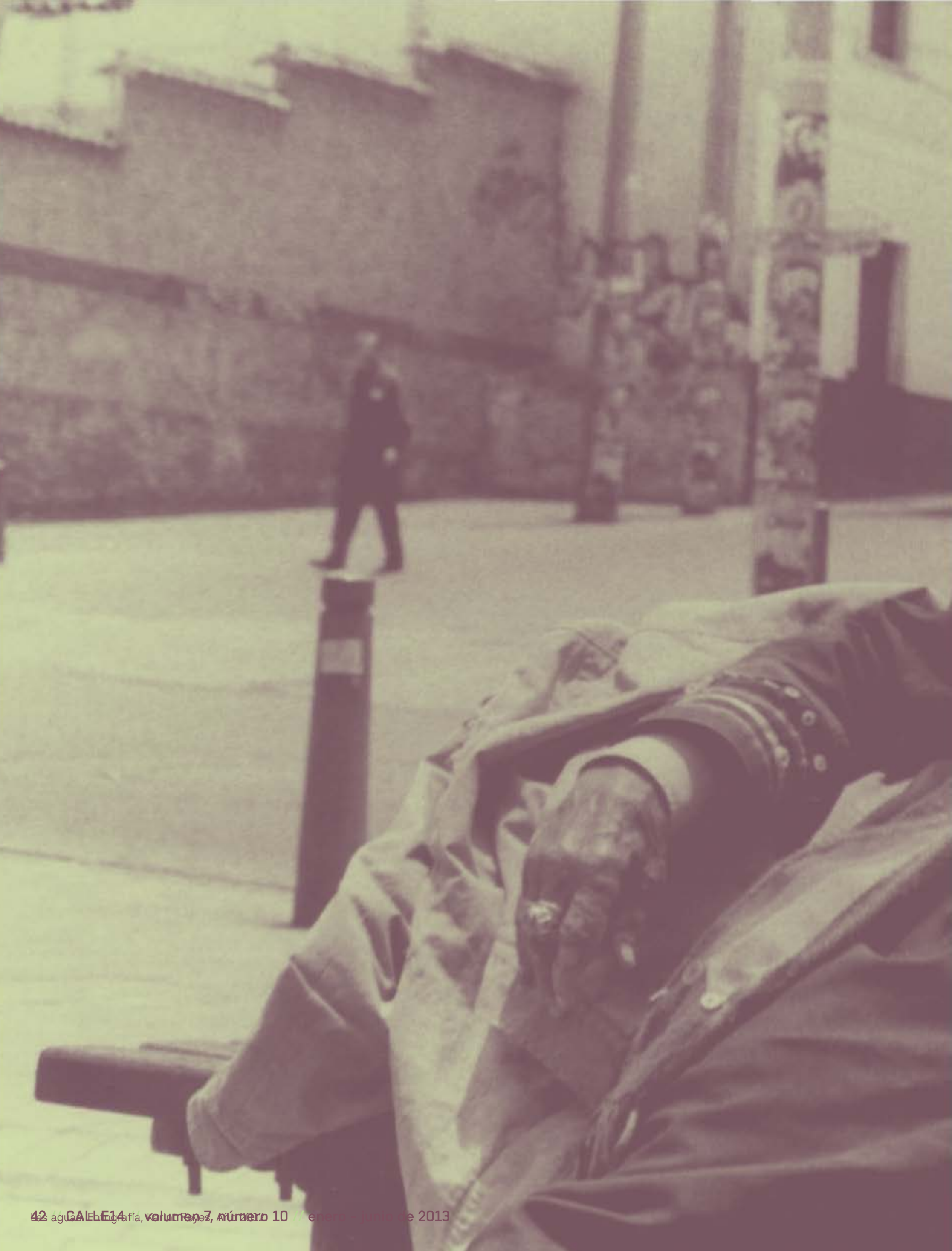



buena fe, quién lo duda, se desvive en desvanecer las diferencias con sus arcangélicas concepciones.

Vargas Llosa cree que asistimos a una disolución de la cultura como especificidad social o individual, sobre lo cual edifica todo su diagnóstico sobre la civilización del espectáculo y sus consecuencias a nivel de la educación e incluso la política. No obstante, al minusvalorar la cuestión de la mercancía y de la mercantilización, Vargas Llosa termina magnificando un asunto que es menor o apenas subsidiario de uno más complejo, que no es otro que el desvanecimiento de los grados y matices que existen entre la cultura y el arte, de las diferencias entre lo cultural y lo artístico, en modo alguno una amalgama de autoría antropológica sacada de cierto romanticismo primitivista, sino una situación sintomática cada vez más difundida propiciada por la mercancía. En efecto, la mercantilización, que tan bien sabe explotar lo esotérico, que tan bien sabe camuflarse en imágenes como la del genio del artista o el encanto de la obra, ha podido de este modo fusionar de manera progresiva cultura y arte implantando, valga el oxímoron aquí más que nunca, auténticos fetiches. ¿Puede haber fetiches auténticos? ¿Puede haberlos no auténticos? Entonces, la fusión de cultura y arte puede terminar reduciendo a meras relaciones sociales de producción económica lo que se presume son relaciones sociales de producción simbólica, agotando la obra de arte, revirtiéndola a simple producto, erosionando con ello cualquier aspiración crítica-emancipadora: el arte, incapaz de trascender la realidad, impotente para proponer una segunda naturaleza, incluso en lo que ella puede tener de catastrófica, se resigna a lo existente, a lo establecido, a lo instituido, solo agraciando la tragedia, siendo cómplice de ella, incluso cuando pretende mostrarse rebelde: la razón cínica. No es aventurado proponer que tantos espectáculos que se promocionan hoy en día en nuestro medio, desde los libros de autoayuda hasta los stand up comedy, no son más que auténticos fetiches, que a las gentes les encantan porque, como en el performance, les pueden mostrar que en un país donde abunda la gente que come mierda y la gente comemierda, bien se puede consagrar a la mierda como obra de arte.

\section{Final}

Sí, el final, que no la conclusión: no se trata de concluir nada. Desde un principio, cuando me invitaron a escribir esta reflexión para la revista Calle 14, me puse a pensar cómo tratar este tema del arte, de la ciudadanía y de la universidad sin caer en abstracciones teóricas, tampoco en prédicas cívicas, mucho menos en ese género de la recomendación, que se ha vuelto tan frecuente. Me puse a pensar en mi propia existencia, en qué había sucedido con las materialidades del mundo, con las cosas y los sonidos, con los colores y las texturas en mis primeros años de desconocimientos y reconocimientos en medio de la vida escolar: pude allí, transitando por entre nostalgias y melancolías, hacerme a este relato alegórico, único en capacidad de disponer a la experiencia en proximidad con la imagen arcana, para permitirle a esta un reflote instantáneo, apenas provisional, para luego subsumirla casi que allí mismo ante la imagen de siempre, esa que perdura quizá imbatible. Las materialidades que perseguía en el relato me remitieron a la luz de las claraboyas, al riel colgado del cable, al piso alquitranado, al pasaje con su olor a hombre loco, a las suelas de los zapatos sobre los rieles, al olor nauseabundo de los oídos cuando fenecen las palabras, al fango de los inviernos, al polvo de los veranos, al olor de los cerezos, de los papayuelos y de los brevos allí por la ruta extraña. Sí, la ruta extraña.

Y entonces, por entre las imágenes arcanas y las superficiales, como alguna vez lo vi, casi al frente de mí, quizá hablándome al oído, estaba de regreso su presencia: sin duda era él, había vuelto, como debía volver, como un espectro, sí, como un fantasma. Una noche, la penúltima antes de estas líneas, estaba sentado allí, al lado de la otra muerta. En todos y cada uno de los pasajes que me traje de mi vida escolar de aquel tiempo, que solo fue un año, Raúl estaba presente, en distintas formas. Seguro que él se hospedó entre todas esas imágenes desde el momento mismo en que sonó el riel anunciando la salida de clases, cuando empezó el bullicio, todo como en los días de siempre. Nadie recuerda de modo exacto, todos dicen que vieron a Raúl correr como de costumbre a donde su mamá, que como era habitual lo esperaba, que como era común lo abrazaba. Todos dijeron que ese día lo había abrazado como nunca antes. Nadie recuerda de modo exacto, el hecho fue que Raúl decidió pasar hasta su casa, sí, allá donde se alzaban las tapias, los cerezos, los papayuelos y los brevos. Su madre le dijo que no era necesario, que luego irían juntos. Pero Raúl no la oyó, porque se supo luego que él no oía entonces ya nada, sus tímpanos estaban gangrenados de infecciones, había perdido cualquier capacidad de escuchar el mundo, incluso a los profesores, que solo tenían para sí que Raúl era un estúpido. Luego lo desdijeron, pero seguro eso pensaron, porque muchas veces lo escribieron en el cuaderno alechugado. Nadie recuerda de modo 
exacto, había algo de fango, pero también estaba el sol, eran los últimos días de septiembre.

Y entonces, corriendo como un loco, ajeno a este mundo primordial venido a menos, Raúl se lanzó hacia la carrilera, que era el paso más rápido hasta su casa. Nadie recuerda de modo exacto, todos dijeron que la máquina, vieja como era, bufó con todas sus fuerzas, que quizá no eran muchas. Otros dijeron que incluso el maquinista alcanzó a gritar de manera desesperada. Nadie recuerda de modo exacto, el hecho es que el tren, como una bestia de otro tiempo, engulló a Raúl entre sus fauces, lo hundió entre los rieles, le pasó por encima dejándolo en pedacitos, para luego detenerse exhausto, veinte o treinta metros más adelante, mientras las gentes gritaban cogidas de la cabeza. El caos había llegado sobre el mundo, la tragedia se había depositado sobre los más infelices y el tren se había hecho a la víctima más inocente, al más ajeno a sus advertencias. De su madre se dijo todo: de los tres segundos de terror que pasaron desde el momento en que Raúl se soltó de su mano y ella vio venir la máquina; de su grito de dolor profundo, de ese llanto que reclama en el instante, que nunca es oído, que le arrancó el aire de un suspiro; de la madre caída, vencida, perdido todo en la catástrofe; del llanto entre los rieles, de su rostro entre la grava, de sus manos entre los despojos. Frente a ella pasaron dos o tres policías corriendo, apenas si la miraron, no hay nadie a quien detener, el asesino también está en sus últimas. Mientras tanto, los muchos que a esa hora todavía salíamos de la escuela quedamos como congelados, incapaces de un solo movimiento, con todos los temores de que viniera otra de estas bestias a consumar sus últimos sacrificios con los niños del barrio, antes de morir de una vez y para siempre.

\section{Referencias}

Adorno, Th. y Horkheimer, M. (2007). Dialéctica de la ilustración. Madrid: Akal.

Bachelard, G. (1997). La poética del espacio. México: Fondo de Cultura Económica.

Bourdieu, P. (1974). “Avenir de classe et causalité du probable". Revue Française de Sociologie, XV: 3-42.

(1977). "Sur le pouvoir symbolique", en Annales. Économies, Sociétés, Civilisations, 3: 405-411.
(1989). La noblesse d'état. Grandes écoles et sprit de corps. Paris: Minuit.

(1994). Esprits d'Etat. Genèse et structure du champ bureaucratique. Raisons pratiques. Sur la théorie de l'action. Paris: Seuil, 99-145.

(1999). Meditaciones pascalianas. Barcelona:

Anagrama.

(1999a). La distinción. Criterio y bases sociales del gusto. Madrid: Taurus.

y A.Darbel. (2003). El amor al arte. Los museos europeos y su público. Barcelona: Paidós.

Castro-Gómez, S. (2009). Tejidos oníricos. Movilidad, capitalismo y biopolítica en Bogotá (1910-1930).

Bogotá: Pontificia Universidad Javeriana.

Durand, G. (1994). Lo imaginario. Barcelona: Del Bronce.

(2000). La imaginación simbólica. Buenos Aires:

Amorrortu.

(2004). Las estructuras antropológicas del imaginario. México: Fondo de Cultura Económica.

Durkheim, E. (2007). Las formas elementales de la vida religiosa. Madrid: Alianza.

Dussel, E. (1993). Las metáforas teológicas de Marx. Navarra: Verbo Divino.

Elias, N. (1997). El proceso de la civilización. Investigaciones psicogenéticas y sociogenéticas. Bogotá: Fondo de Cultura Económica.

Evans-Pritchard, E.E. (1976). Brujería, magia y oráculos entre los azande. Barcelona: Anagrama.

Foucault, M. (2006). Seguridad, territorio, población. Curso en el Collège de France (1977-1978). Buenos Aires: Fondo de Cultura Económica.

(2007). Nacimiento de la biopolítica. Curso en el Collège de France (1978-1979). Buenos Aires: Fondo de Cultura Económica.

Gartman, D. (2013). Culture, class, and Critical Theory. Between Bourdieu and the Frankfurt School. Routledge: Nueva York. 
Girard, R. (2005). La violencia y lo sagrado. Barcelona: Anagrama.

Gravagnuolo, B. (1998). Historia del urbanismo en Europa, 1750-1960. Madrid: Akal.

Habermas, J. (2010). Teoría de la acción comunicativa. Madrid: Trotta.

Herf, Jeffrey (1990). El modernismo reaccionario. Tecnología, cultura y política en Weimar y el Tercer Reich. México: Fondo de Cultura Económica.

Hofer, A. (2003). Karl Brunner y el urbanismo europeo en América Latina. Bogotá: El Áncora y Corporación La Candelaria.

Kantorowicz, E. (1985). Los dos cuerpos del rey. Un estudio de teología política medieval. Madrid: Alianza.

Klibansky, R., Panofsky, E. y Saxl, Fritz (2012). Saturno y la melancolía. Estudios de historia de la filosofía de la naturaleza, la religión y el arte. Madrid: Alianza.

Michaud, E. (2009). La estética nazi. Un arte de la eternidad. La imagen y el tiempo en el nacional-socialismo. Buenos Aires: Adriana Hidalgo.

Panofsky, E. (2007). La arquitectura gótica y la escolástica. Madrid: Siruela.

Sennett, R. (1994). Carne y piedra. El cuerpo y la ciudad en la civilización occidental. Madrid: Alianza.

Serna Dimas, A. (2006). "Saberes educativos y saberes sociales: esbozo para una historia social de sus estructuras institucionales", en Estructura, tiempo y sujeto. Nuevos recursos para la discusión interdisciplinaria. Bogotá: Universidad Distrital Francisco José de Caldas, 101-146.

Taussig, M. (1995). "Maleficium: el fetichismo del Estado", en Un gigante en convulsiones. El mundo humano como sistema nervioso en emergencia permanente. Barcelona: Gedisa, 144-180.

Vargas Llosa, M. (2012). La civilización del espectáculo. Bogotá: Alfaguara.
Warburg, A. (2005). El renacimiento del paganismo. Aportaciones a la historia cultural del paganismo europeo. Madrid: Alianza.

Weber, M. (1997). Economía y sociedad. Esbozo de sociología comprensiva. Bogotá: Fondo de Cultura Económica. (2005). El político y el científico. Madrid: Alianza.

Yates, F. (2005). El arte de la memoria. Madrid: Siruela. 
